Review

\title{
Biomedical Applications of Biodegradable Polyesters
}

\author{
Iman Manavitehrani, Ali Fathi, Hesham Badr, Sean Daly, Ali Negahi Shirazi and \\ Fariba Dehghani *
}

Received: 30 November 2015; Accepted: 11 January 2016; Published: 16 January 2016

Academic Editor: Esmaiel Jabbari

School of Chemical and Biomolecular Engineering, University of Sydney, NSW 2006, Australia; iman6901@uni.sydney.edu.au (I.M.); ali.fathi@sydney.edu.au (A.F.); hbad9313@uni.sydney.edu.au (H.B.); sean.daly@sydney.edu.au (S.D.); ali.negahi@sydney.edu.au (A.N.S.)

* Correspondence: fariba.dehghani@sydney.edu.au; Tel.: +612-9351-4794

\begin{abstract}
The focus in the field of biomedical engineering has shifted in recent years to biodegradable polymers and, in particular, polyesters. Dozens of polyester-based medical devices are commercially available, and every year more are introduced to the market. The mechanical performance and wide range of biodegradation properties of this class of polymers allow for high degrees of selectivity for targeted clinical applications. Recent research endeavors to expand the application of polymers have been driven by a need to target the general hydrophobic nature of polyesters and their limited cell motif sites. This review provides a comprehensive investigation into advanced strategies to modify polyesters and their clinical potential for future biomedical applications.
\end{abstract}

Keywords: polyesters; biodegradable; medical applications; tissue engineering

\section{Introduction}

The current market for regenerative implantation surgeries, therapeutic cell culturing and tissue repair is approximately US $\$ 23$ billion, and it is anticipated to reach US $\$ 94.2$ billion by the end of 2025 [1]. Synthetic biodegradable polyesters are considered the most commercially competitive polymers for these applications as they can be produced reproducibly in a cost-effective manner with a wide range of characteristics. Polyesters are also biocompatible, and biodegradable polymers are used for the manufacturing of different medical devices, such as sutures, plate, bone fixation devices, stent, screws and tissue repairs, as their physicochemical properties are suitable for a broad range of medical applications [2-5]. Polyesters are also used commercially in controlled drug delivery vehicles [6,7].

In all of the current commercial products, polyesters act as a biologically inert supporting material as a mesh or a drug-releasing vehicle. For more advanced medical and regenerative applications, polyesters are modified to tackle issues such as low cell adhesion, hydrophobicity, and inflammatory side-effects $[8,9]$. Consequently, the modification of polyesters has been one of the major research topics in the fields of material engineering and polymer science.

In this review, the properties of polyesters and the modification methods that have been implemented to improve some of the shortcomings of this class of polymers are discussed. Specifically, this review covers the applications and modifications of the most commonly used polyesters such as polylactic acid (PLA), poly(lactic-co-glycolic acid) (PLGA), poly(e-caprolactone) (PCL), poly-3-hydroxybutyrate (or poly- $\beta$-hydroxybutyric acid, PHB), poly(3-hydroxybutyrate-co-3-hydroxyvalerate) (PHBV), poly(propylene carbonate) (PPC), poly(butylene succinate) (PBS) and poly(propylene fumarate) (PPF).

\section{Synthesis of Polyesters}

Polyesters are produced predominantly by using random polymerization, ring opening polymerization, and the block copolymerization techniques. For instance, PCL is produced by the ring 
opening polymerization of the $\varepsilon$-caprolactone using a catalyst such as an octoate [10]. The synthesis methods have been extensively reviewed in detail by many researchers; therefore, these synthesis approaches are not discussed in detail in this review [11-15]. The vast majority of the polyesters are derived from carbohydrate petroleum-based sources. Therefore, in recent decades, there has been a drive to find alternative sustainable polymers. Among all the polyesters, only PPC, PHB and PLA come from renewable sources.

PPC is produced in commercial scale from the ring opening reaction between $\mathrm{CO}_{2}$ and propylene oxide in the presence of an active catalyst such as zinc glutarate [16]. Similar ring opening polymerization mechanisms that are used to synthesise PPC and PCL are also used to synthesise PLA. The synthesis of PLA is a multi-step fermentation process starting with the biosynthesis of lactic acid. Lactic acid is then converted to its cyclic lactide foam and then polymerized via a metal catalyst $[17,18]$.

PHB entirely is biosynthesized by an efficient fermentation process with different molecular weight (from 200 to $1500 \mathrm{kDa}$ ) using diazotrophic bacteria of acetobacter and Rhizobium genus [19]. PHB is primarily a product of carbon assimilation and it is employed by microorganisms as a form of energy storage molecules. The polycondensation of two molecules of acetyl-CoA leads to the formation of acetoacetyl-CoA that can be reduced to hydroxybutyric-CoA and polymerize PHB. However, the biosynthesis process of $\mathrm{PHB}$ is chirally selective and the resulting polymer typically has a polydispersity of around 2 or higher [20].

\section{Properties of Polyesters}

Linear aliphatic polyesters are mostly hydrophobic biodegradable polymers [21]. Their tunable physical and mechanical properties have extended their applications in the biomedical field [22]. It is easy to process these materials into desired structures with minimal risks of toxicity, immunogenicity, and infection. The main differentiating characteristics of polyesters are their mechanical performance and degradation behaviors that are discussed extensively as follows.

\subsection{Mechanical Strength}

In regenerative medicine, the mechanical property of a polymer plays a vital role in the selection of a biomaterial for any application. A robust biomaterial that does not mimic the mechanical strength of the targeted tissue interferes with the natural regeneration mechanism, and, ultimately, is a drawback for the damaged tissue repair [23]. The mechanical performance of bone, cartilage and cardiovascular tissues that are mostly treated with polyester-based implants are summarized in Table 1. In addition, this table outlines the mechanical performance of different polyesters and some medical devices. Medical devices such as screws and meshes are designed from polymers with the ultimate elongation strength of $200 \mathrm{MPa}$ to fix cortical bones with the compression strength of 100-200 MPa.

There are numerous medical applications for polyester due to their broad range of mechanical properties. For instance, PGA has a relatively brittle structure as its ultimate strain is $30 \%$. Therefore, PGA is not a desirable polyester for the fabrication of medical meshes as they are normally under high tensile strain. On the other hand, PPC displays a very flexible structure as its ultimate elongation at break is nearly $330 \%$, which is at least five-fold higher than other polyesters. However, PPC may deform under elongation as this polymer displays very low tensile modulus, e.g., $22 \mathrm{MPa}$. Therefore, PPC is not a favorable candidate for the fabrication of medical screws, sutures, and meshes that are under constant tensile stress. PLGA and PLA posse significantly higher tensile modulus and strength compared to PPC. PLA displays the highest tensile stress $\left(\sigma_{\mathrm{m}}=55 \mathrm{MPa}\right)$ and favorable ultimate elongation at breakage $\left(\varepsilon_{\mathrm{m}}=30 \%-240 \%\right)$; hence, it has been broadly used for the fabrication of devices that are under constant tensile stress and high elongation. 
Table 1. Mechanical properties of the biodegradable polyesters and a few tissues and commercially available biomaterials.

\begin{tabular}{|c|c|c|c|c|c|}
\hline Material & Type & $\begin{array}{l}\text { Tensile modulus } \\
\text { (E, MPa) }\end{array}$ & $\begin{array}{c}\text { Ultimate tensile } \\
\text { strength }\left(\sigma_{\mathrm{m}}, \mathrm{MPa}\right)\end{array}$ & $\begin{array}{l}\text { Elongation at } \\
\text { break }\left(\varepsilon_{\mathrm{m}}, \%\right)\end{array}$ & Reference \\
\hline \multirow{3}{*}{ Tissues } & Bone (trabecular) & 483 & 2 & 2.5 & [24] \\
\hline & Cartilage & $10-100$ & $10-40$ & $15-20$ & [25] \\
\hline & Cardiovascular & $2-6$ & 1 & 1200 & [26] \\
\hline \multirow{3}{*}{ Medical devices } & $\begin{array}{c}\text { Mg-based } \\
\text { orthopaedic screw }\end{array}$ & Not reported & $\sim 200$ & $\sim 9$ & [27] \\
\hline & Suture & $\sim 850$ & $\sim 37$ & $\sim 70$ & [28] \\
\hline & $\begin{array}{l}\text { Medical mesh } \\
{\left(\text { Vicryl }^{\circledR}\right)}\end{array}$ & $\begin{array}{c}4.6 \pm 0.6 \\
\text { (stiffness } \mathrm{N} / \mathrm{mm} \text { ) }\end{array}$ & $\begin{array}{c}78.2 \pm 10.5 \\
\text { (maximum force } \mathrm{N} / \mathrm{cm} \text { ) }\end{array}$ & $150 \pm 6$ & [29] \\
\hline \multirow{8}{*}{ Polyesters } & PGA & $7000-8400$ & 890 & 30 & [30] \\
\hline & PLGA(50:50) & $\sim 2000$ & 63.6 & $3-10$ & {$[31,32]$} \\
\hline & PLA & 3500 & 55 & $30-240$ & [33] \\
\hline & PHB & 3500 & $\sim 40$ & $5-8$ & [34] \\
\hline & PPF & $2000-3000$ & 3-35 & 20.3 & {$[22,35,36]$} \\
\hline & PCL & $\sim 700$ & $4-28$ & $700-1000$ & {$[30,31]$} \\
\hline & PPC & 830 & 21.5 & 330 & [37] \\
\hline & PBS & $\sim 700$ & $\sim 17.5$ & $\sim 6$ & {$[38]$} \\
\hline
\end{tabular}

\subsection{Degradation}

An essential element in biomedical applications of polymers is the development of a temporary physical and mechanical support for the regeneration of newly formed tissues over time. Information about the degradation rate of a polymer is imperative for the design of various medical devices. For instance, a slow degradation rate of PLA provides the opportunity for the production of long-term orthopedic implants such as plates and screw [39-41]. However, PGA-based biomaterials are mainly used for the fabrication of sutures and drug delivery carriers due to their fast degradation [42,43]. Moreover, the rate of the degradation of polymers needs to be balanced to assure that the implanted device or the scaffold can provide the required mechanical strength for the regeneration of the newly formed tissue over time. For instance, in one case, a PLA-based implant, after an arthroscopic surgery, failed to regenerate the tissue and showed no signs of degradation, which resulted in some clinical complications for the patient [44].

The degradation is governed by different factors such as the nature of the polymer, composition, molecular weight, crystallinity, structure, thickness, surface properties and environmental conditions. The mechanical strength of a medical device or implant is also a function of degradation rate. For instance, molecular weight has a direct correlation with the rate of degradation, the higher molecular weight leads to slower degradation due to lengthy polymer chains [45]. However, the degree of crystallinity of some polyesters such as PLLA can proportionally affect the direct relationship between molecular weight and the degradation rate [46]. The indirect effect of crystallinity on the degradation rate is controversial as a few groups show that crystallinity of polyesters increases the degradation rate due to an increase in hydrophilicity $[47,48]$. In contrast, some groups display a slower rate with an increase in sample crystallinity [49].

The rate of degradation depends on the intrinsic chemical properties of polymers as well as the physical properties and the shape of the implant or device. The physical properties are important because the water diffusion and, consequently the hydrolysis of the polymer structures are affected by the contact surface area of the implants with the body fluids. Therefore, the degradation rates of different polyesters are reported within a range. Most of the polyesters are stable in the body for at least 12 months except PGA and its copolymer PLGA. This polymer has been copolymerized from LA and GA to acquire a relatively fast degradable polymer for medical applications. The degradation rate of PLGA can also be altered by changing the molar ratios of LA to GA. For instance, increasing the 
weight ratio of the GA to LA from 25:75 to 50:50 can accelerate the degradation by two-fold from 100 to 50 days.

Hydrolytic and enzymatic degradation are the primary mechanisms of degradation of polyesters through bulk- or surface degradation of implants [50]. Hydrolytic degradation has an autocatalytic nature and it proceeds through the hydrolysis of carboxylic groups of hydroxy acids [51], whereas the enzymatic degradation significantly depends on the enzyme that is responsible for the degradation of a specific molecule [52]. PCL, for instance, undergoes lipase-type enzymatic degradation in the presence of Rhizopus delemer lipase [53], Rhizopus arrhizus lipase, and Pseudomonas lipase [54]. Among these enzymes, Pseudomonas lipase significantly accelerates the process to totally degrade the highly crystalline PCL within four days [55], in contrast with hydrolytic degradation, which lasts several years. The general mechanism of degradation of polyesters is by bulk hydrolysis [56]. The presence of some enzymes may expedite the degradation of some of the polyesters. As a result of bulk degradation, there is a risk of a sudden loss in the structural stability of a polymeric structure.

It is critical to examine the biocompatibility and toxicity of any degradation product of a polymer for the design of biomedical devices. By-products of a bulk degradation of a polymer are released in the surrounding environment such as the host tissue. For instance, the release of acidic by-product from the degradation of PLA or PLGA may drop the $\mathrm{pH}$ of surrounding tissues and lead to cell necrosis and inflammation at the site [57-59]. It is therefore imperative to quantify the biodegradation products of polymers in order to study the biological behavior of the host environment upon the degradation of polymers systematically. The average logarithmic acid dissociation constant, $\mathrm{p} K_{\mathrm{a}}$, of the intermediate degradation products of polyesters is used to quantify the acidity of the resulting products upon their degradation. The $\mathrm{p} K_{\mathrm{a}}$ of the degradation products, the primary mechanisms of the degradation, and the in vivo degradation rate of the different polymers are summarized in Table 2.

Table 2. The degradation behavior of the biodegradable polyesters.

\begin{tabular}{|c|c|c|c|}
\hline Polyesters & Degradation by-products (pKa) & In vivo degradation rate & Degradation mechanism \\
\hline PLA (PLLA and PDLA) & Lactic acid (3.85) [60] (3.08) [61] & $\begin{array}{c}50 \% \text { in } 1-2 \text { years [62] } \\
98 \% \text { in } 12 \text { months [63] } \\
100 \% \text { in }>12 \text { months [64] } \\
100 \% \text { in } 12-16 \text { month [31] }\end{array}$ & $\begin{array}{l}\text { Hydrolysis through the action } \\
\text { of enzymes [33] }\end{array}$ \\
\hline PGA & Glycolic acid (3.83) [61,65] & $\begin{array}{c}100 \% \text { in } 2-3 \text { months [62] } \\
100 \% \text { in } 6-12 \text { months [64] }\end{array}$ & $\begin{array}{c}\text { Both enzymatic and } \\
\text { non-enzymatic hydrolysis [62] }\end{array}$ \\
\hline PLGA & $\begin{array}{l}\text { Lactic acid (3.85)[60] (3.08) [61] } \\
\text { Glycolic acid (3.83) [61,65] }\end{array}$ & $\begin{array}{c}100 \% \text { in } 100 \text { days }(75 \% \\
\text { LA: } 25 \% \text { GA) }[66] \\
100 \% \text { in } 50-100 \text { days }[62]\end{array}$ & $\begin{array}{l}\text { Hydrolysis through the action } \\
\text { of enzymes [31] }\end{array}$ \\
\hline PPC & $\begin{array}{l}\mathrm{CO}_{2} \text { and Water (pathway and } \\
\text { intermediates unknown) }\end{array}$ & $\begin{array}{l}6 \% \text { in } 200 \text { days [67] } \\
\text { No degradation after } \\
2 \text { months [68] }\end{array}$ & $\begin{array}{l}\text { Hydrolysis, or enzyme } \\
\text { mediation [69] }\end{array}$ \\
\hline PHB & $\begin{array}{l}\text { 3-Hydroxybutyric acid (4.41 [70] } \\
\text { or } 4.7[71])\end{array}$ & $\begin{array}{c}35 \% \text { degradation of molecular } \\
\text { weight after } 6 \text { months [72] } 60 \% \\
\text { degradation via thickness of pellet } \\
\text { after } 24 \text { weeks [73] }\end{array}$ & $\begin{array}{l}\text { Hydrolysis via nonspecific } \\
\text { esterase enzymes }[74,75]\end{array}$ \\
\hline PHBV & $\begin{array}{l}\text { 3-Hydroxybutyric acid (4.41 [70] } \\
\quad \text { or } 4.7[61,71]) \\
\text { 3-hydroxyvaleric acid (4.72 [61]) }\end{array}$ & $\begin{array}{l}75 \% \text { degradation via thickness of } \\
\text { pellet after } 24 \text { weeks [73] }\end{array}$ & $\begin{array}{l}\text { Hydrolysis via nonspecific } \\
\text { esterase enzymes }[74,75]\end{array}$ \\
\hline PBS & $\begin{array}{c}\text { Succinic acid (4.21 and } 5.64 \text { for the } \\
\text { first and second } \\
\text { hydroxyl group) [76] }\end{array}$ & $\begin{array}{l}5-10 \text { wt } \% \text { in } 100 \text { days } \\
\text { (In vitro) [76] }\end{array}$ & $\begin{array}{l}\text { Enzymatic hydrolytic } \\
\text { degradation [77] }\end{array}$ \\
\hline PCL & Caproic acid (4.88) [78] & $\begin{array}{l}50 \% \text { in } 4 \text { years [62] } \\
1 \% \text { in } 6 \text { months [79] }\end{array}$ & Hydrolytic degradation [79] \\
\hline PPF & Fumaric acid $\left(\mathrm{pK}_{\mathrm{a} 2}=4.44\right)[22]$ & $\begin{array}{l}\text { Depends on the formulation and } \\
\text { composition several } \\
\text { months }>24 \text { [22] }\end{array}$ & Hydrolysis [80] \\
\hline
\end{tabular}

Most of the polyesters, except PLA, PLGA, and PGA display a $\mathrm{p} K_{\mathrm{a}}$ of $4-5$, which is considered a relatively weak acidic environment, thus, the resulting biological inflammatory responses might not be severe. For instance, the haematoxylin and eosin staining results as displayed in Figure 1 shows that after eight weeks of PPC and PLA implantations in mice, there was no immune response to the 
PPC implant, whereas multi-layer fibrous tissues were noted around the PLA constructs due to the acidic degradation of this polymer. These results illustrate the favorable degradation properties of PPC [81]. Furthermore, it should be noted that the degradation byproducts of PHB can be useful for cell growth [82]. The average reported $\mathrm{p} K_{\mathrm{a}}$ of the degradation products from PLA, PGA and PLGA are nearly 3.5, which can be considered as a semi-strong acidic environment. Therefore, upon clinical application of these polymers, care must be taken to ensure their long-term degradation.

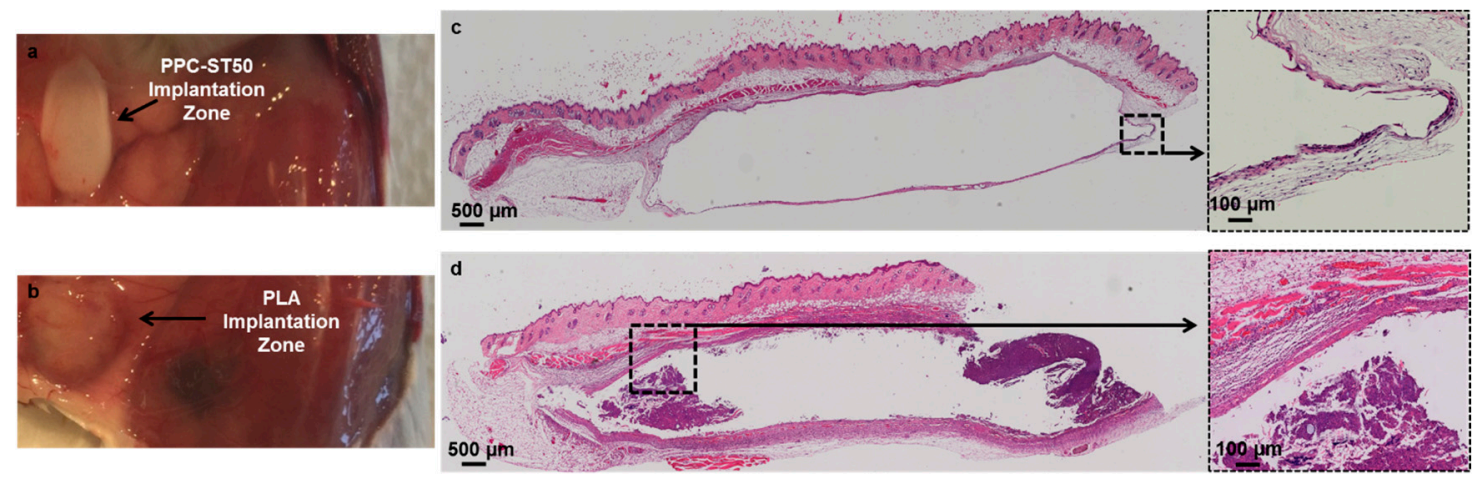

Figure 1. The explanation site of PPC-ST50 (a) and polylactic acid (PLA) (b) eight weeks post-surgery, and haematoxylin and eosin staining of paraffin sections of the implantation site at eight weeks around PPC-ST50 composite (c) and PLA (d). After eight weeks, a prominent foreign body reaction could be observed in the PLA implantation zone. However, the inflammatory response to the PPC-ST50 composite resolved dramatically. The PPC-ST50 and PLA scaffolds are present in the H\&E images may not adhere to the glass slides during histological staining. Figure reproduced with permission from [81]. Copyright (2015) American Chemical Society.

\subsection{Commercial Application of Polyesters}

PLGA, PLA, and PCL are amongst the most widely used polyesters for the fabrication of sutures, drug delivery and implants as summarized in Table 3. PLGA has been used in commercial sutures since the 1970s (e.g., Vicryl ${ }^{\circledR}$ with the latest and most widely used PGA-sutures on the market as Vicryl Rapide ${ }^{\circledR}$ and Panacryl ${ }^{\circledR}$, manufactured by Ethicon Inc., Edinburgh, United Kingdom) [83]. In addition, PLGA has been used for drug delivery applications, e.g., Lupron $\operatorname{Depot}^{\circledR}$, Sandostatin ${ }^{\circledR}$ Depot, and Risperdal ${ }^{\circledR}$ Consta $^{\circledR}$ [83]. PCL is used for the fabrication of tissue repair patches (i.e., Ethicon Inc., Edinburgh, United Kingdom) and as a filling agent to fill non-load bearing cavities in bone. PHB based biomaterials are mainly sutures (i.e., Phantom Fiber ${ }^{\mathrm{TM}}$ (Tornier Co., Amsterdam, The Netherlands), MonoMax ${ }^{\circledR}$ (Braun Surgical Co., Melsungen, Germany)) and surgical mesh such as TephaFlex ${ }^{\circledR}$ mesh (Tepha Inc., Lexington, MA, USA), GalaFLEX mesh (Galatea Corp., Lexington, MA, USA) and Tornier ${ }^{\circledR}$ surgical mesh (Tornier Co., Amsterdam, The Netherlands). Furthermore, a few medical disposable products are available in the market made of PBS such as Bionolle ${ }^{\circledR} 1000$ and 3000 (Showa Highpolymer Co. Ltd., Tokyo, Japan).

For load bearing applications, PLA is the most used polyester due to its intrinsic high mechanical strength (56.96 MPa compression and 3500 MPa tensile modulus) [33]. PLA is used in internal fixation devices, such as screws, plates, pins, and rods to support the repair of broken bones and hold them together [84]. However, in vivo studies show that PLA interferes with the bone remodeling process by imbalancing the number of osteoblast and osteoclasts during the bone remodeling [85,86]. Considering the commercially available polyester-based products as shown in Table 3, it can be observed that such products are mainly used as non-load bearing biomedical applications due to some unmet drawbacks. It is well-acknowledged that chemical and physical alterations of current-biodegradable polyesters are promising for enhancing their applications in the biomedical field. These approaches can be exploited to further extend the medical use of polyesters. 
Table 3. Commercial products made from biodegradable polyesters and their applications.

\begin{tabular}{|c|c|c|}
\hline Polymers & Applications & Commercial products \\
\hline PLGA & $\begin{array}{l}\text { (Composition 85:15): Interference screws [25], plates [25], } \\
\text { suture anchors [25], Stents [38]/(Composition 50:50): } \\
\text { Suture [25], drug delivery [25], Articular cartilage } \\
\text { repair [39]/(Composition 90:10): Artificial skin [25], wound } \\
\text { healing [25], hernia repair [2], suture [2], tissue engineered } \\
\text { vascular grafts [2] }\end{array}$ & $\begin{array}{l}\text { Rapidsorb }^{\circledR} \text { plates (DePuy Synthes CMF, West } \\
\text { Chester, PA,USA), Lactosorb }^{\circledR} \text { TraumaPlatingSystem } \\
\text { (Biomet, Inc., Warsaw, IN, USA) [L-lactide/glycolide } \\
\text { = 82/18], RFS }{ }^{\mathrm{TM}} \text { Screw System (Tornier), RFS } \\
\text { (Resorbable Fixation System) Pin System (Tornier), } \\
\text { Xinsorb BRS }{ }^{\mathrm{TM}} \text { stent (Huaan Biotechnology Group, } \\
\text { Gansu, China) REF1, Dermagraft }{ }^{\circledR} \text {, Vicryl }{ }^{\circledR} \text { woven } \\
\text { mesh (Ethicon Inc.) (Composition 90:10) }\end{array}$ \\
\hline PCL & $\begin{array}{l}\text { Suture coating [25], dental orthopedic implants [25], Tissue } \\
\text { repair [2], hybrid tissue-engineered heart valves [2], Surgical } \\
\text { meshes [2], cardiac patches [31], Vascular grafts [32], Adhesion } \\
\text { Barriers [33], Dural substitutes [2], Stents [34], Ear implants [2], } \\
\text { Tissue engineering scaffolds [16,35] }\end{array}$ & $\begin{array}{l}\text { Tissue repair patches (Ethicon Inc.), Bulking and } \\
\text { Filling agents (Angelo, 1996), DermaGraft' } \\
\text { (Organogenesis Inc., Canton, MD, USA) }\end{array}$ \\
\hline PPF & $\begin{array}{l}\text { Orthopedic implants [25], dental [25], foam coatings [25], drug } \\
\text { delivery [25], Scaffolds [8,12] }\end{array}$ & - \\
\hline PPC & Scaffolds $[87,88]$ & - \\
\hline РHB & $\begin{array}{l}\text { Sutures (P4HB polymer) [2], screw fasteners for meniscal } \\
\text { cartilage repair, Scaffold for tendon repair [2], Reconstructive } \\
\text { surgeries (Surgical meshes) [2], Vascular grafts [32], Nerve } \\
\text { repair [36,37], Bone tissue scaffold (P3HB) [26], Wound } \\
\text { dressing (P3HB) [2], hemostats (P4HB) [2], Stents [38] }\end{array}$ & $\begin{array}{l}\text { Phantom Fiber }{ }^{\mathrm{TM}} \text { suture (Tornier Co.), MonoMax }{ }^{\circledR} \\
\text { suture (Braun Surgical Co.), BioFiber }{ }^{\mathrm{TM}} \text { scaffold } \\
\text { (P4HB polymer) (Tornier Co.), TephaFlex }{ }^{\circledR} \text { mesh } \\
\text { (Tepha Inc.) (P4HB polymer), GalaFLEX mesh } \\
\text { (Galatea Corp.), Tornier }{ }^{\circledR} \text { surgical mesh (Tornier Co.) }\end{array}$ \\
\hline PHBV & Scaffolds $[89,90]$ & - \\
\hline PBS & $\begin{array}{l}\text { Stents [2], Sterilization wrap [2], Diagnostic or } \\
\text { Therapeutic Imaging }\end{array}$ & $\begin{array}{l}\text { Disposable Medical Products-Bionolle }{ }^{\circledR} 1000 \text { and } \\
3000 \text { (Showa Highpolymer Co. Ltd.) }\end{array}$ \\
\hline
\end{tabular}

\section{Modification of Polyesters}

Polyesters are broadly used for biomedical applications. However, different approaches are undertaken to address their shortcomings. Polyesters are commonly hydrophobic with a low number of cell-motif sites within their structures which results in inferior cell interaction behavior. Different physical and chemical modification techniques have been used to enhance their biological activities that are briefly described in this section.

In the physical modification, the molecular structure of polymers is not changed and an additional component(s) is mixed with the polymer; either by solvent casting or melt blending techniques. In the chemical modification, the molecular structure of the polymer is changed. There are two pathways; (a) copolymerization of the building blocks of polyesters to form a new class of polymers; and (b) modification of the polymer chain of the polyesters post-synthesis. In the following sections, the physical and chemical modification methods of the most used biodegradable polyesters for biomedical applications are discussed.

\subsection{PLA}

According to the European Bioplastics Association, more than 142,000 tons of PLA was consumed in 2013 which is more than $11.4 \%$ of the global bioplastic production capacity [91]. In biomedical applications, this polymer is also the most commonly used, and, thus, has been extensively modified by incorporating different organic and inorganic components. Additionally, PLA is the only member of the polyester family that has been used for load bearing applications such as orthopedic screws and plates, owing to the high mechanical strength of this polymer [92,93]. The properties of PLA depend on its molecular characteristics, crystallinity, morphology and degree of chain orientation.

Lactic acid, the building monomer of PLA, provides chiral configuration for PLA including D and L-polylactic acid. For load bearing applications, L-PLA is preferable because of the high strength and toughness of the resulting polymer; however, D-PLA is used in drug delivery systems due to 
its faster degradation rate. Three different crystallinity of the PLA including $\alpha, \beta$, and $\gamma$ forms are available. These three crystalline structures of PLA ( $\alpha, \beta$, and $\gamma$ forms) display melting points of 185 , 175 and $235{ }^{\circ} \mathrm{C}$, respectively [94]. Regardless of the crystalline structure, and chiral configurations, PLA exhibits a very hydrophobic nature and a low ultimate elongation strain of nearly $10 \%$ [95]. In addition, PLA degradation in the body decreases the $\mathrm{pH}$ of surrounding tissues substantially, which may cause clinical complications such as necrosis and delayed healing. Similar to all other polyesters, the lack of cell motif sites within the structure of this polymer has also been a significant driving force to modify PLA. Therefore, PLA has been changed (a) to enhance its hydrophilic properties; (b) to increase the ultimate elongation strain; (c) to address the formation of acidic biodegradation products; (d) to improve the bioactivity; (e) and to increase the number of cell motif sites within its structure. Table 4 summarizes some of these physical and chemical modification approaches.

Table 4. Polylactic acid (PLA)-based structures applied in biomedical and tissue engineering applications.

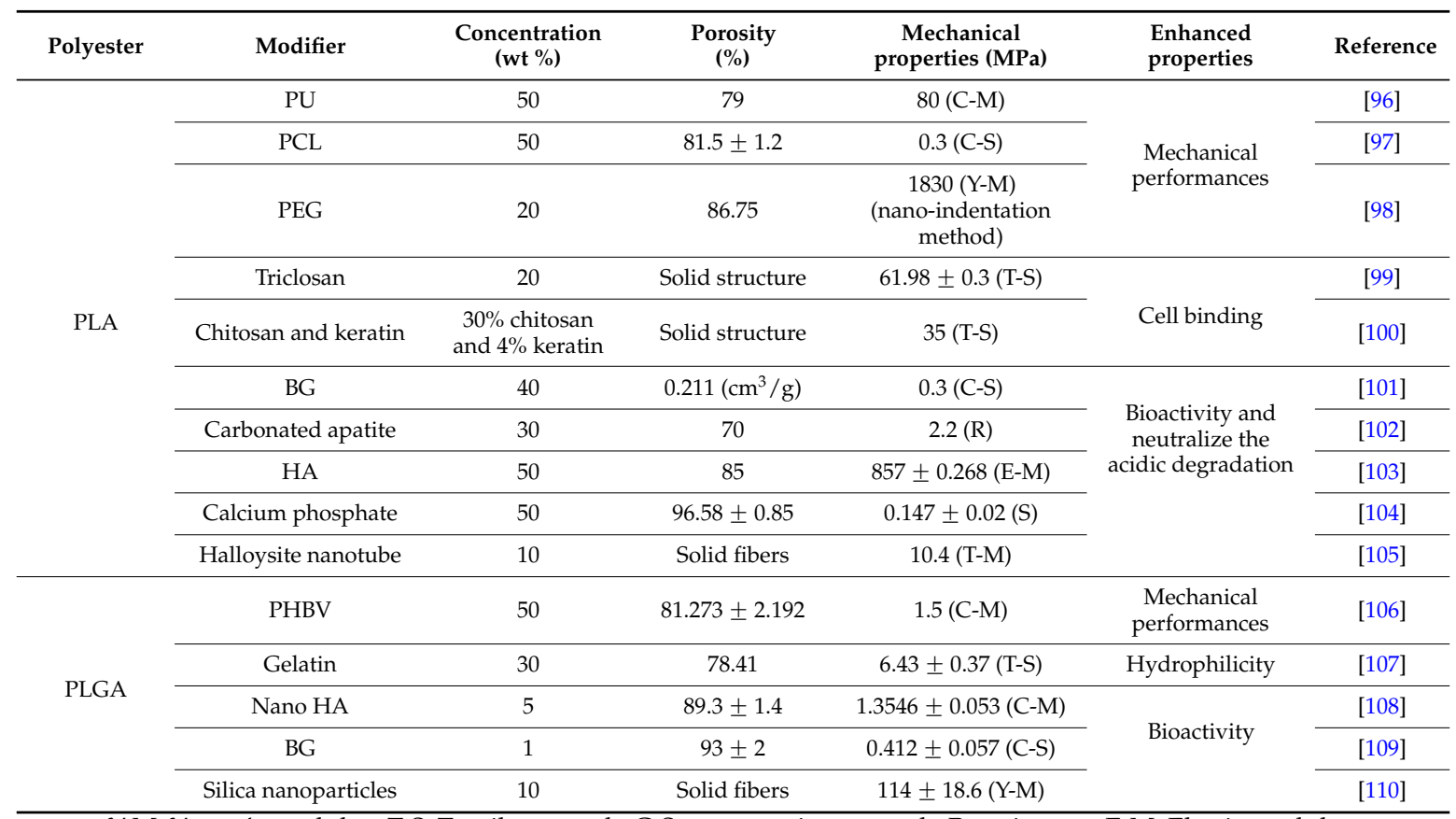

Y-M: Young's modulus; T-S: Tensile strength; C-S: compressive strength; R: resistance; E-M: Elastic modulus; S: stiffness; T-M: Tensile modulus; C-M: Compressive modulus.

The primary motivation to chemically modify PLA and to copolymerize lactic acid with glycolic acid to form PLGA was to develop a polymer with a more hydrophilic nature that degrades into less acidic products. This concept was initially hypothesized as glycolic acid has higher (more neutral) $\mathrm{p} K_{\mathrm{a}}$ compared with lactic acid. However, the degradation products of PLGA are lactic acid and glycolic acid, and both of them still lower the $\mathrm{pH}$ of the surrounding tissue. In addition, PLGA displays a faster degradation rate, which is favorable for biomedical applications such as bioabsorbable sutures or drug delivery devices. Therefore, in parallel with PLA, the medical use of PLGA has also been expanded and, thus, a wide range of physical and chemical modifications have been made to both PLA and PLGA to enhance their properties.

The mechanical properties of PLA are favorable for load bearing applications, and the only mechanical shortcoming of PLA is its low ultimate tensile strain (e.g., around 10\%). To enhance this property of PLA, thermoplastic polyurethane (TPU) and PCL have been physically added to this polymer [96,97]. TPU can tune its tensile modulus within the range of 7-1007 MPa at the strain of above $15 \%$ for neat PLA and a blend with 1:1 weight ratio, respectively. While, the addition of $50 \mathrm{wt} \%$, PCL increases the elongation at break by nearly 10 fold (107\% $\pm 4.7 \%)$. PLGA intrinsically displays very stretchable behavior with high ultimate tensile strain. However, the elongation and compression 
moduli of this polymer are lower than PLA, which drives the use of PLA for load bearing applications. In few cases, PLGA is blended with other polymers such as PHBV, which is a brittle but stiff polymer (high tensile modulus), to enhance the compression modulus and tensile moduli by two to three fold [106].

For tissue regeneration applications, the cell interaction behavior of PLA and PLGA-based composites needs to be improved, and the first material of choice to address this challenge is natural polymers, such as polysaccharides, polypeptides, and proteins. Tanase $e t$ al. introduced a polyester blend modified with chitosan and keratin to enhance cell interactions of the polyester [100]. An in vitro cell study using human osteosarcoma cell line shows a good cell viability and proliferation. Furthermore, the incorporation of polyethylene glycol (PEG) into the PLA matrix is used to enhance the surface hydrophilicity, and therefore, its biological behavior [98]. However, the addition of PEG results in a decrease in mechanical performance.

The cell interaction of PLGA also needs to be improved. Similar to PLA, natural polymers have been widely used to enhance the cell interaction capability of PLGA. Accordingly, PLGA knitted mesh is modified with collagen type I to develop a supporting biomaterial for cartilage and bone regeneration applications [111,112]. For chondrocyte growth and proliferation to help cartilage repair, 3D biodegradable scaffolds were formed with a different configuration of collagen inside the PLGA matrix and led to homogeneous cell distribution, natural chondrocyte morphology, and abundant cartilaginous ECM deposition. However, the mechanical strength of the most promising scaffold was at least half of the requirement for cartilage regeneration [111]. In another study, laminated mesh of PLGA and collagen was modified this time for bone-cartilage interface reconstruction. In this study, the collagen microsponge was crosslinked by treatment with $25 \%$ glutaraldehyde saturated vapor to cover the surface of the PLGA knitted mesh. The tissue engineered scaffold possessed the same behavior as a native osteochondral plug nine weeks after post-implantation regarding DNA expression of collagen type I and II. Another research group modified the surface of PLGA with poly-L-lysine using a water-in-oil-in-water emulsion or solvent evaporation technique [113]. Surface modification promoted the cell differentiation; however, it showed an adverse effect on the mechanical properties of PLGA. Gelatin was also used to modify a biodegradable polyester microfiber using electrospinning [107]. These examples demonstrate that various strategies can be used to enhance the biological properties of PLA and PLGA by incorporating natural polymers. The addition of natural proteins and polysaccharides, however, cannot potentially address the acidic degradation products and low bioactivity of PLA. To tackle this problem and to enhance the bioactivity of the PLA and PLGA based constructs, bioactive ceramics can be added to PLA, as the degradation products of ceramics are mostly basic and can promote the proliferation of native bones in the load bearing applications of these polymers.

There are numerous studies as summarized in Table 4 that investigates the effect of adding bioactive ceramics such as hydroxyapatite (HA) and $\beta$-tricalcium phosphate $(\beta-\mathrm{TCP})$ to neutralize the acidic degradation media of polyesters and to evoke bioactive properties to these polymers $[57,114]$. The results of these studies demonstrate that the basic degradation of ceramic particles can neutralize the acidic environment. In a more clinical-based study, a method is developed for the treatment of skull defects by using PLA plates supplemented with carbonated apatite bone cement [115]. In these implantable plates, carbonated apatite cement particles are dispersed into the PLA sheets and are fixed to skull fractures. After 3-60 months' follow-up, no complications concerning dislodgement or structural failure of the cranioplasty construct were observed. Several studies reported the positive impact of adding bone cement particles within the structure of PLA to enhance the cell interaction and bioactivity of PLA based structures [116,117]. Care must be taken to prepare a homogeneous composite of ceramic-polymer to achieve suitable mechanical properties and also predictable degradation behavior.

Hydrolysis by an alkali is the first step of chemical modification to provide an active site on the surface of a polymer [118]. In this procedure, the ester bond of biodegradable polymer is activated 
to bond with the hydrophilic $-\mathrm{COOH}$ and $-\mathrm{OH}$ or reactive $-\mathrm{NH}_{2}$ groups in components such as an arginine-glycine-aspartic acid (RGD)-containing peptides, chitosan (CS), arginine and lysine, PEG, collagen, etc. Enhancement of wettability of the surface and biocompatibility of the scaffold are the main aims of these surface modifications. For instance, a PLA modified with RGD results in improvement in the cell densities and proliferation mediated through RGD-integrin interactions [119]. In spite of all the mentioned advantageous features for the polymers driven by post-polymerization, the possibility of side reactions, such as chain scission and racemization along with the complexity of this process, are the main disadvantages of this method. Therefore, post-polymerization functionalization is not the preferred route to obtain functional polyesters, and, also, these methods are not practical for the formation of 3D structures [21].

Advanced chemical modification methods are carried out to improve the physical and biological characteristics of both PLA and PLGA for the fabrication of 3D structures [21]. A general synthetic route for functionalization of PLA is copolymerization with 3-(S)-[(benzyloxycarbonyl)methyl]-1,4dioxane-2,5-dione protected with benzyl alcohol followed by diazotization with sodium nitrite [120]. The deprotection process performed via catalytic hydrogenolysis of the benzyl groups using both $\mathrm{PtO}_{2}$ and $\mathrm{Pd} / \mathrm{C}$ catalysts results in an enhanced in vitro hydrolysis rate compared to PLA. The monomer functionalization has been extensively studied; however, few types of research evaluated the monomer functionalized polyesters for tissue engineering applications due to unknown biological properties that may lead to clinical complications [121-124].

The ring opening copolymerization of lactic acid through its carboxyl and hydroxyl groups is a possible way to chemically modify PLA and can produce high molecular weight polymers in combination with glycolide, $\delta$-valerolactone, and trimethylene carbonate, as well as with monomers like ethylene oxide [125]. For instance, for drug delivery application, a range of PLA-PEG copolymers have been synthesized by using PEG block with a certain molecular weight and varying PLA segment lengths (e.g., $\left.M_{n}=2000-110,000\right)$ using ring-opening polymerization of D,L-lactide catalyzed by stannous octoate [126]. Furthermore, PLA copolymerized with polyurethanes by copolymerization of L-LA and 1,4-butanediol to acquire mechanical properties for soft tissue engineering [127]. In addition to these general approaches to enhancing the physical and biological properties of PLA-based materials, more advanced polymer synthesis methods have been employed to make more clinically appropriate PLA-based materials. For instance, to eradicate the need for using organic solvents, there are numerous studies that attempt to generate water-soluble forms of PLA by grafting different molecules to this polyester.

Polymer grafting such as chitosan-grafted-PLA can be prepared by attaching PLA to the chitosan main chain, and these materials can be dissolved in low $\mathrm{pH}$ aqueous based solution [128,129]. PLA and PEG were also functionalized with $\mathrm{FuCl}$ to form a water soluble and crosslinkable form of PLA. This polymer has been extensively studied and analyzed by Jabbari's research group [130-134]. In yet another study, a green approach was developed to synthesize this polymer under high-pressure $\mathrm{CO}_{2}$ to eradicate even the use of organic solvent during its synthesis [135]. Conducting the synthesis in $\mathrm{CO}_{2}$ gas expanded solution remarkably increased the fumarate crosslinking active site in the backbone of poly(lactide-ethylene oxide fumarate) (PLEOF) copolymer, hence, enhancing the mechanical properties and osteoblast cell adhesion and proliferation $[135,136]$. Interpenetrated polymer networks of PLEOF reinforced with gelatin and methacrylated gelatin were also synthesized with enhanced primary human osteoblast cell adhesion and proliferation [137,138]. As shown in Figure 2, these interpenetrating polymer network structures were composed of micro $(\sim 20 \mu \mathrm{m})$, and macropores $(540 \mu \mathrm{m})$ pores that promote the nutrient mass transfer and cell growth, respectively. 

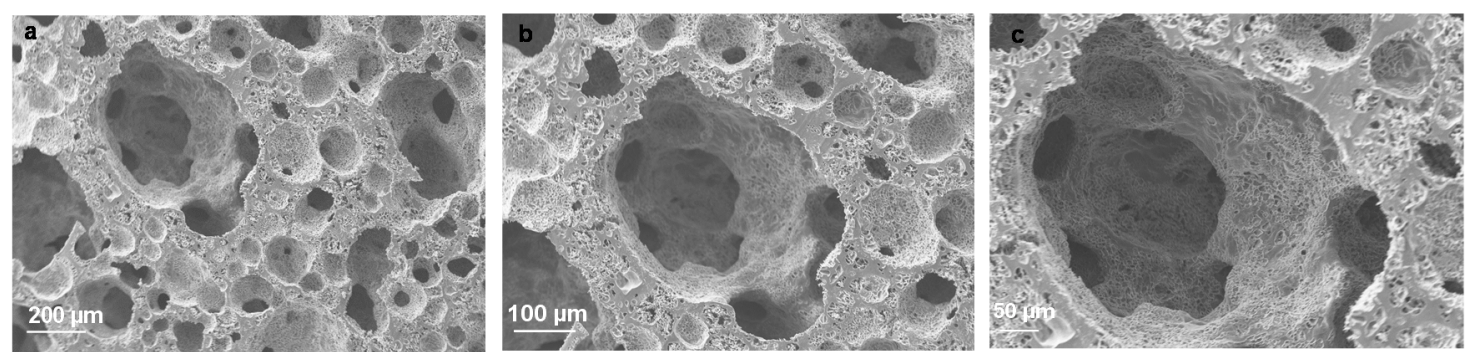

Figure 2. The micro and macroporous structure of PLEOF-methacrylated gelatin interpenetrated network. Figure reproduced from [138], with permission from Elsevier.

To form injectable hydrogels for various medical applications, we further chemically modify PLA [139]. In this approach, we copolymerized PLA with hydroxyethyl methacrylate (HEMA) with a ring-opening polymerization technique. The resulting PLA/HEMA was then conjugated with a number of monomers, e.g., NIPAAM, NAS, and OEGMA to form water soluble, temperature responsive and protein reactive molecules. These polymers can be used for cartilage and bone regeneration applications [140-142]. All these chemical modification approaches demonstrate the polyesters are modifiable and their properties can be tuned for a broad range of medical applications.

\subsection{PHA Family}

Polyhydroxyalkanoates (PHAs) are synthetic biodegradable polyesters that can be biosynthesized with the fermentation of microorganism, and can also be chemically synthesized [143]. PHA is produced by the biosynthesis pathway through acetyl-CoA which leads to the production of PHB [144]. PHB and PHBV are the most thoroughly studied forms of the PHA family for biomedical applications due to their biocompatibility, biodegradability, and adjustable mechanical properties. The biodegradation of PHB and other PHA derivatives are driven by hydrolysis of the ester bond $[74,75]$. Their degradation products, such as a $\beta$-hydroxybutyric acid (3HB) and 3-hydroxyvaleric acid, are less acidic than lactic and glycolic acid with $\mathrm{pK}_{\mathrm{a}}$ values of 4.7 [71] and 4.72 [61], respectively. The mechanisms of PHB degradation are thermal, enzymatic or hydrolytic. Hydrolytic degradation of PHB releases $3 \mathrm{HB}$, which is a normal metabolite in human blood; therefore, in the absence of endotoxin, the biodegradation of PHB produced by bacteria does not cause any physiological reaction. Moreover, $3 \mathrm{HB}$ by itself has pharmaceutical and biomedical applications as its derivatives decrease cell apoptosis $[61,145]$. This property provides a unique feature for regeneration and drug delivery applications of PHB and other polymers in the PHA family.

Propionate, valerate, hexanoate, and 1,4-butanediol can be added to produce random copolymers and block polymers, such as poly(3-hydroxybutyrate-co-3-hydropropionate), poly(3-hydroxybutyrate-co-3 -hydroxyvalerate) (PHBV), poly(3-hydroxybutyrate-co-3-hydroxyhexanoate), and poly(3-hydroxybutyrateco-4-hydroxybutyrate) [144,146]. Poly(3-hydroxybutyrate-co-3-hydroxyhexanoate) is another member of PHA family that is physically blended with PHB. The main limiting factors for the medical applications of the PHA family are (a) low ultimate tensile strain (b) minimal cell interaction capacity. To tackle these shortcomings, these polymers have been combined with numerous other natural and synthetic polymers. Table 5 summarizes some of the modifications that have been carried out on PHB and PHBV. 
Table 5. The physicochemical modifications of the polyhydroxyalkanoates (PHA)-based polyesters in the field of biomedical and tissue engineering.

\begin{tabular}{|c|c|c|c|c|c|c|}
\hline Polyester & Modifier & $\begin{array}{l}\text { Concentration } \\
(w t \%)\end{array}$ & $\begin{array}{l}\text { Porosity } \\
(\%)\end{array}$ & $\begin{array}{c}\text { Mechanical properties } \\
\text { (MPa) }\end{array}$ & $\begin{array}{l}\text { Enhanced } \\
\text { properties }\end{array}$ & Reference \\
\hline \multirow{3}{*}{ PHB } & HA & 30 & Solid film & 1400 (S-M) & \multirow{3}{*}{ Bioactivity } & [147] \\
\hline & Herafill & 30 & Solid film & $2800(\mathrm{Y}-\mathrm{M})$ & & [148] \\
\hline & BG & 10 & 85 & Not reported & & [149] \\
\hline \multirow{4}{*}{ PHBV } & Chitin & 10 & Not reported & $7.12 \pm 0.24(\mathrm{C}-\mathrm{M})$ & Cell binding & [89] \\
\hline & Silk and nHA & $5(w / v) \%$ & $71.44 \pm 0.81$ & $0.72 \pm 0.26(\mathrm{Y}-\mathrm{M}(\mathrm{kPa}))$ & \multirow{3}{*}{ Bioactivity } & [150] \\
\hline & Calcium silicate & 20 & 80 & $\sim 33^{1}(\mathrm{C}-\mathrm{M})$ & & [151] \\
\hline & HA & 10 & Solid fibers & $4.19 \pm 0.19(\mathrm{U}-\mathrm{S})$ & & [152] \\
\hline
\end{tabular}

C-M: Compressive modulus, Y-M: Young's modulus, S-M: storage modulus, T-S: Tensile strength; 1. After 12 weeks implantation.

Chitosan, chitin, and chondroitin sulfate are used to improve the biological and mechanical elongation properties of the PHA family [89,90]. For instance, after adding $10 \mathrm{wt} \%$ of chitin nanocrystals, the compressive modulus of PHA increases by $28 \%$ from $5.21 \pm 0.14 \mathrm{MPa}$ to $7.12 \pm 0.24 \mathrm{MPa}$. The different weight ratio of PEO (polyethylene oxide) is also used to improve the tensile strength and the elongation at break of PHB [153]. The results showed that the addition of $10 \mathrm{wt} \%$ PEO improves the tensile strength by $40 \%$ while maintaining the elongation at break at a constant value; however, adding $50 \mathrm{wt} \%$ PEO causes a $69 \%$ decrease in the tensile strength while increasing the elongation at break significantly. Therefore, PHB blend exhibits more elastic properties with lower toughness in comparison with PHB homopolymer.

Nano-HA, bioactive glass, tricalcium phosphate, calcium silicate, zirconium dioxide and herafill ${ }^{\circledR}$ are some examples of inorganic compounds that have been added to PHB and PHBV to increase their bioactivity and cell interaction capacity for bone implants and tissue engineering [148-152,154-157]. For instance, the addition of $20 \mathrm{wt} \%$ calcium silicates enhances the cell adhesion, distribution and proliferation and bone-bioactivity of the composite. Furthermore, the introduction of micro and nanoparticles of $45 \mathrm{~S} 5$ Bioglass grades, to interconnect a highly porous $\mathrm{PHB}$ with $85 \%$ porosity, results in the formation of a HA layer with a $\mathrm{Ca} / \mathrm{P}$ ratio of 1.57 after 10 days of being immersed in SBF. This rapid formation of HA within this short period reveals that the fabricated composite is highly bioactive and favorable for bone regeneration applications. However, the $\mathrm{pH}$ of the degradation media increased to 8.5 after the addition of $10 \mathrm{wt} \%$ nano BG particles due to the basic degradation of ceramics that may lead to some clinical complications.

The chemical modification of PHB via either graft copolymerization or in situ polymerization or multi-block copolymerization was also studied [158]. To this end, the hydroxyl end group of PEG is first functionalized with acryloyl chloride to form PEGM (polyethylene glycol methacrylate). Then, the free radical copolymerization of acrylates groups of PEGM under UV irradiation takes place in chloroform. The resulted copolymer was shown to possess significantly higher equilibrium water content that may lead to a more hydrophilic structure than that of PHB, which is vital for cell interaction in biomedical applications.

The full potential of PHB for tissue engineering and drug delivery applications has not yet been exploited. This is because, the mixing of PHB with other polymers is technically challenging: PHB is soluble in very few solvents, i.e., chloroform, dichloromethane, and dimethyl formamide, which is a hindrance for the solvent casting method and the formation of composite structures. In addition, thermal molding is also challenging, as above $150{ }^{\circ} \mathrm{C}$ most of the PHA based polymers break down to fatally toxic trans-crotonic acids. Addressing these challenges may open up an avenue for further modification of PHA polymers and their future medical applications.

The exceptional stereochemical regularity of PHB that leads to a high degree of crystallinity in the range of $60 \%-80 \%$ is another limiting factor for the biomedical application of PHB [159]. This highly crystalline structure along with tacticity is the main material characteristics of PHB that affects 
the processability of PHB. Chemical modification of this biodegradable polyester such as multi-block copolymerization with PEG can decrease the degree of crystallinity of PHB and extend the applications of this polymer in the biomedical field [160].

\section{3. $P P C$}

PPC is a biodegradable aliphatic polyester that was first synthesized by the copolymerization of carbon dioxide $\left(\mathrm{CO}_{2}\right)$ and propylene oxide at the end of the 1960s [161]. PPC is an amorphous biodegradable polyester, and its thermal properties such as thermal decomposition, melting temperature and glass transition temperature are in the range of $240-260{ }^{\circ} \mathrm{C}, 150-170{ }^{\circ} \mathrm{C}$ and $37-42{ }^{\circ} \mathrm{C}$, respectively $[69,162,163]$. Comparable thermal, mechanical, biocompatibility and degradation properties of PPC with other aliphatic polyesters, which have been broadly used in tissue engineering, motivate researchers to investigate the feasibility of using PPC as a biomaterial [87,164-167]. The final degradation products of PPC are $\mathrm{CO}_{2}$, and water, which could solve the issue of inflammation that commonly occurs during the degradation of other polyesters. The biodegradation mechanism of PPC, e.g., the nature of the resulting intermediate substances, is not clearly understood [164].

The first biocompatibility of PPC was proved by Kavaguchi et al. at 1983 [165]. The results demonstrated that PPC is a biocompatible polyester because there was no inflammatory response and retardation in animals leads to weight gain. In addition, the degradation of PPC has been studied for its use as a surgical polymer, or as a slow-release substrate in the peritoneal cavity in rats. As a consequence of the small surface area of pellets that were implanted in rats, the degradation of PPC was negligible within two months. Another study by Kim et al. [164] focused on evaluating the biodegradation of PPC. Three different mechanisms including oxidative degradation, hydrolytic degradation, and enzymatic degradation have been proposed, but enzymatic degradation has been selected as the primary process. The cell attachment on PPC is very limited due to its highly hydrophobic nature. Therefore, PPC is physically and chemically modified for biomedical applications. The effect of some modification processes is summarized in Table 6.

The surface hydrophilicity of PPC based constructs has been enhanced by using well-established surface modification techniques such as UV irradiation and plasma coating $[167,168]$. Low-power deep UV radiations were used to enhance the cell attachment and proliferation on the surface of electrospun PPC [167]. This surface treatment led to a higher adsorption of the protein layer followed by an improvement in cell attachment. Oxygen plasma treatment method was also used to enhance the wettability of PPC based constructs. To this end, parallel-aligned PPC microfibers with a fiber diameter of $1.48 \pm 0.42 \mu \mathrm{m}$ were prepared firstly; then, chitosan nanofibers with a fiber diameter size of $278 \pm 98 \mathrm{~nm}$ were introduced into the PPC fiber mats by freeze drying. Oxygen plasma treatment at a pressure of 0.025 mtorr and radio power generating oxygen plasma $100 \mathrm{~W}$ was used. The surface modification resulted in the fall of water contact angle from $122.3^{\circ} \pm 0.4^{\circ}$ for neat PPC scaffolds to $53.8^{\circ} \pm 1.6^{\circ}$ for plasma treated samples. However, it should be noted that the initial reported contact angle data for neat PPC conflicts with other literature, which have reported an average of $76^{\circ}[164,169]$. The cell attachment, proliferation, and cell-scaffold interactions were enhanced in PPC microfibers and chitosan nanofibers. 
Table 6. Organic and inorganic components added to the poly(propylene carbonate) (PPC) matrices.

\begin{tabular}{|c|c|c|c|c|c|c|}
\hline Polyester & Modifier & $\begin{array}{l}\text { Concentration } \\
(w t \%)\end{array}$ & $\begin{array}{c}\text { Porosity } \\
(\%)\end{array}$ & $\begin{array}{l}\text { Mechanical properties } \\
\text { (MPa) }\end{array}$ & Enhanced properties & Reference \\
\hline \multirow{6}{*}{ PPC } & Chitosan & 5 & 91.9 & $14.2 \pm 0.56(\mathrm{C}-\mathrm{M})$ & \multirow{3}{*}{$\begin{array}{l}\text { Hydrophilicity and } \\
\text { cell binding }\end{array}$} & [87] \\
\hline & Chitosan & 7 & Solid fibers & $5.0 \pm 0.8$ (T-S) & & [168] \\
\hline & PEI and Gelatin & Coating & 92.3 & $0.4(\mathrm{C}-\mathrm{M})$ & & {$[166,169]$} \\
\hline & Graphene oxide & 1 & 83.54 & $1(\mathrm{C}-\mathrm{M})$ & \multirow{3}{*}{$\begin{array}{l}\text { Physical characteristics } \\
\text { such as mechanical } \\
\text { performances and } \\
\text { porosity }\end{array}$} & [170] \\
\hline & Gelatin & 15 & Solid fibers & $2.88 \pm 0.82$ (T-S) & & {$[88]$} \\
\hline & Starch & 50 & Solid disk & 33.9 (C-M) & & [81] \\
\hline
\end{tabular}

For the fabrication of 3D structures with more favorable hydrophilic properties and cell behavior characteristics, PPC is mixed with other natural polymers. A composite of PPC and gelatin, in trifluoroethanol as a solvent and at low mass content of gelatin, with improved wettability and hydrophilicity was produced by Jing et al. [88]. Gelatin was used in this study to improve the cell attachment and proliferation of scaffolds; however, phase separation occurred when the mass content of gelatin was higher than $5 \%$ due to the usage of immiscible solvent. The phase separation resulted in the formation of a non-uniform fibrous structure and large splash defects. The study shows that the PPC/gelatin composite scaffolds exhibit better performance in the wettability and mechanical tests as well as cell culture experiments when compared to those of pure PPC frameworks. On the same topic, to address the phase separation challenge, micro- and nano-fibers of PPC and chitosan were separately generated and mixed subsequently [168]. The miscibility of graphite within the structure of PPC was also challenging. Graphite with an average size of $7.4 \mu \mathrm{m}$ and a nanometer-sized thickness of 30-50 nm was used to improve the physical properties of PPC [171]. This research revealed that poor dispersion occurs in composite films with high graphite content, and the maximum value of $2 \mathrm{wt} \%$ graphite shows better morphological structures, thermal properties, mechanical properties and barrier properties. Another study investigates the usage of graphene oxide (GO) to fill PPC matrix to enhance its mechanical performance [172]. The dispersion of the filler within the structure of PPC was also technically challenging.

GO-PPC composite preparation was carried out in solution phase; while a certain amount of $\mathrm{GO} / \mathrm{H}_{2} \mathrm{O}$ solution was added to the PPC/tetra hydro furan solution. To this end, syringe titration was used to avoid coagulation of PPC in water. Toughening PPC with rubbery non-isocyanate polyurethane (NIPU) was also considered [173]. The equilibrium between self-associating hydrogen bonding and intermolecular interaction formed between PPC and NIPU was shown to affect the miscibility and the morphology of the blends. Moreover, the study showed that the addition of $10 \mathrm{wt} \%$ of NIPU leads to a three-fold increase of impact strength in comparison to neat PPC. However, when the NIPU loading reached $13 \mathrm{wt} \%$, NIPU agglomerated in the matrix leading a decline in toughness.

Using the solvent casting method for the modification and processing of PPC based construct is challenging. This is because, similar to PHA based families, PPC is only soluble in few solvents such as dichloromethane and tetrahydrofuran [69]. The use of a thermal blending method, therefore, is deemed to be the most convenient way to form composite structures. This melt blending process has been widely used to produce a PPC-polysaccharide blend for packaging purposes [174-177]. More recently, it has been shown that a composite of PPC and starch can be produced via a melt blending method that enhances the physical characteristics of polyester and eradicates the miscibility issue [81]. However, the starch microparticles that are embedded into the PPC matrix were thoroughly covered by the hydrophobic PPC. A new emerging strategy to increase the hydrophilicity of the polyesters is the usage of plasticizers such as glycerol and sorbitol [178]. This problem was alleviated by the addition of plasticizers such as glycerol and water during PPC and thermoplastic starch blending [179]. This innovation led to the fabrication of a biodegradable plastic bag without using any cytotoxic plasticizer, which could have implications for future biomedical applications. 


\section{4. $P B S$}

The poly(alkaline dicarboxylate) family of polymers are biodegradable polyesters. PBS is the most commonly used polymer in this family of polymers due to its relatively low production cost, good thermal and mechanical properties, and ease of processability $[180,181]$. The primary degradation product of PBS is succinic acid that is an intermediate of the tricarboxylic acid cycle or Krebs cycle; thus, it degrades inside the body with final products of water and carbon dioxide [182]. An important factor that limits the application of PBS in the biomedical field is its hydrophobicity with the reported contact angle of $75.03 \pm 0.38$ that causes little cell interaction [183]. Composites of PBS with different hydrophilic polymers were formed to enhance the wettability and potentially the biological properties of the polyester [184-186].

An electrospun composite microfiber of PBS and PEG was developed for tissue regeneration. The primary intention in order to blend these two polymers was to use PEG as a porogen by leaching it in an aqueous solution. However, the complete removal of the porogen was not feasible due to the low porosity of the fabricated structure, leading to the formation of a composite semi-porous PBS/PEG structure. The composite displayed more hydrophilic properties, but the cell interaction capacity of the polymer was limited, as neither of the polymers had any cell motif sites [186]. The melt blends of PBS and chitosan scaffolds with a $50 \mathrm{wt} \%$ filler have been used for cartilage and bone tissue engineering by multiple research groups $[182,184,185]$. The solubility of PBS and chitosan in acidic aqueous solutions allows for the formation of one phase solution and, thus, the formation of composite structures. The PBS/chitosan biodegradable scaffold supported the osteogenic differentiation of human bone mesenchymal stem cells cultured on their surface in vitro. The culture media was supplemented with osteogenic additives. Results from this study, therefore, cannot fully confirm the osteogenic nature of the PBS/chitosan. Another in vivo study in nude mice validates bone growth at the site of the cranial defect by implanting PBS/chitosan scaffolds with pre-cultured mesenchymal stem cells. The microCT analysis shows that the bone healing process began eight weeks post-implantation. This result is not very promising as bone regeneration after eight weeks is common in normal healing processes. Additionally, the Western blot assay reveals that the bone marrow-derived mesenchymal progenitor cell line cultured on the scaffold was being differentiated toward the chondrogenic pathway for periods of up to three weeks [182].

Chitin and chondroitin sulfate nanoparticle are added to the PBS to improve the cell motif of the biodegradable polyester to provide cell adhesion for skin tissue engineering [187]. Human dermal fibroblast cells adhered and proliferated on the surface of the scaffold and proved the suitability of the constructs for skin regeneration. Live-dead assay of the cells on the surface of the composite structure exhibits a significant improvement in cell viability due to the acceleration of wound healing because of the enhancement of the influx of fibroblasts into the wound, the increase of proteoglycan synthesis and collagen-II and also the exertion of anti-inflammatory activity. To fabricate PBS based composites for bone regeneration applications, HA particles are added to PBS films. To this end, a biomimetic method that involved the formation of HA layer on the PBS ionomer inside SBF was used. [188]. In this novel approach, sodium sulfonate ionic groups with negative charges were found to lead to the binding of plenty of the $\mathrm{Ca}^{2+}$ ions on the surface of PBS and form a stable layer of HA, which is favorable for the ingrowth of the surrounding tissue and bone formation. Furthermore, $20 \mathrm{wt} \% \beta$-tricalcium phosphates (TCP) were added to the PBS to possess in vitro osteoblast growth and differentiation [189]. Results revealed that the incorporation of calcium phosphate not only improves the bioactivity of the scaffold but also increases the wettability of the films by $23.89 \%$ that is satisfactory for cell ingrowth.

Different chemical and physical modification approaches have been carried out on PBS to increase the hydrophilicity and the biological properties of this polymer. However, the most prominent drawback for the clinical application of this polymer is its brittle nature. As an illustration, PBS has the lowest ultimate elongation strain $(6 \%)$ with one of the lowest ultimate tensile strengths (17 MPa) among all polyesters. To the best of our knowledge, there is no research that endeavors to improve the 
stretchability of this polymer. Addressing this important drawback of PBS may expand the application of this polymer in biomedicine and tissue regeneration.

\subsection{PCL}

Poly ( $\varepsilon$-caprolactone) is an aliphatic polyester that has been widely considered for biomedical applications including drug delivery and tissue engineering [190]. Its compatibility with a broad range of drugs enables uniform drug distribution in the formulation matrix, and its long-term degradation facilitates drug release up to several months [191]. The homopolymer PCL has a total degradation of two to four years (depending on the starting molecular weight of the polymer) with hydrolysis as the primary degradation mechanism [10]. Pitt et al. showed that the mechanism of in vivo degradation of PCL, PLA, and their random copolymers was qualitatively the same [10]. PCL was studied extensively for tissue engineering applications, such as scaffold for bone tissue engineering, and other advanced 3D prototype blend composites for hard tissue engineering [192]. Among PCL's commercial applications, a monofilament suture, MONOCRYLs ${ }^{\circledR}$, which is made of a PCL-Glycolide copolymer and a contraceptive product, Capronor ${ }^{\circledR}$, which can deliver a drug for over a year, has been commercially available for over 25 years [83]. PCL is modified to enhance the cell binding capacity, to increase its compression and tensile strength and also to accelerate the degradation rate of this polyester. Some modification approaches to PCL are summarized in Table 7.

Table 7. Modification methods of poly ( $\varepsilon$-caprolactone) (PCL)-based composites for biomedical and tissue engineering applications.

\begin{tabular}{|c|c|c|c|c|c|c|}
\hline Polyester & Modifier & $\begin{array}{l}\text { Concentration } \\
\text { (wt \%) }\end{array}$ & $\begin{array}{l}\text { Porosity } \\
(\%)\end{array}$ & $\begin{array}{c}\text { Mechanical properties } \\
\text { (MPa) }\end{array}$ & Enhanced properties & Reference \\
\hline \multirow{9}{*}{ PCL } & Chitosan & 25 & Solid fibers & $1.78 \pm 0.25(\mathrm{~T}-\mathrm{S})$ & \multirow{3}{*}{$\begin{array}{l}\text { Hydrophilicity and } \\
\text { cell binding }\end{array}$} & [193] \\
\hline & $\begin{array}{l}\text { Gelatin and } \\
\text { Collagen }\end{array}$ & $\begin{array}{l}20 \% \text { gelatin } \\
\text { and } 1.5 \% \\
\text { collagen }\end{array}$ & Solid fibers & 1.29 (T-S) & & [195] \\
\hline & Alginate & 5 & 92 & $0.72 \pm 0.04$ (T-S) & & [196] \\
\hline & Nanofiber PLA & 10 & 79.7 & Not reported & \multirow{3}{*}{$\begin{array}{l}\text { Physical characteristics } \\
\text { such as mechanical } \\
\text { properties and } \\
\text { porosity }\end{array}$} & [197] \\
\hline & MWNTs & 2 & Solid disk & 110 (T-M) & & [198] \\
\hline & $\begin{array}{c}\text { Phlorotannin } \\
\text { nanofibers }\end{array}$ & 5 & Solid fibers & $57.8 \pm 6.6(\mathrm{Y}-\mathrm{M})$ & & [199] \\
\hline & BG & 50 & Solid disk & $\sim 190$ (E-M) & \multirow{3}{*}{$\begin{array}{l}\text { Degradation behavior } \\
\text { and bioactivity }\end{array}$} & [202] \\
\hline & $\mathrm{nBG}$ & 30 & $8 \pm 5$ vol $\%$ & $383 \pm 50(\mathrm{E}-\mathrm{M})$ & & [203] \\
\hline & $\begin{array}{l}\text { Calcium } \\
\text { phosphate }\end{array}$ & 10 & Solid fibers & $7.55 \pm 0.70(\mathrm{Y}-\mathrm{M})$ & & [204] \\
\hline
\end{tabular}

E-M: Elastic modulus; T-M: Tensile modulus; C-M: Compressive modulus; Y-M: Young's modulus; T-S: Tensile strength.

Natural-based fillers such as alginate, chitosan, gelatin, collagen and eggshell powder were used to improve the cell compatibility and hydrophilicity of PCL [193-196,205-207]. For instance, the addition of $10 \mathrm{wt} \%$ alginate resulted in an eight-fold enhancement in water absorption, 1.6-fold enhancement of cell viability at seven days, $\sim 2.3$-fold enhancement of ALP activity at 14 days and $\sim 6.4$-fold enhancement of calcium mineralization at 14 days. In addition, chitosan-PCL composite supported neuron-like PC-12 cell adhesion and showed a significantly higher $\beta$-tubulin gene expression. A composite of gelatin, chitosan and PCL were used for cardiac tissue engineering. This proposed cardiac patch had a sufficient mechanical strength along with allowing migration or pre-loading of cardiac cells in a biomimetic environment. Collagen type I was also coated on the surface of PCL and PCL-gelatin composite for skin tissue engineering and wound healing applications. The optimum adhesion, 
viability and proliferation of L929 fibroblast cells on the surface of the composite were observed after surface modification with $1 \mathrm{wt} \%$ collagen type I. In another study, a semi-interpenetrating polymer network structure of PCL and elastin was prepared. In this approach, we initially fabricated a porous structure of PCL by using a gas foaming technique. Subsequently, elastin was impregnated within the structure of PCL under high-pressure $\mathrm{CO}_{2}$ and crosslinked in situ as it can be seen in Figure 3 . In vitro studies with chondrocyte showed that the incorporation of elastin within the structure of PCL enhances cell proliferation and adhesion, [208,209]. Therefore, these scaffolds may be suitable for cartilage tissue regeneration.

The composites of PCL with inorganic/organic compounds such as graphene, multiwall carbon nanotubes (MWCNTs), PEG, PLA and PU have been prepared to enhance its mechanical properties [197,198,210-213]. The graphene and MWCNTs were mainly used for electro-responsive tissue types and improvement of mechanical performances. However, adverse effect on cell viability and proliferation was observed when using graphene and MWCNTs above 1 and $0.5 \mathrm{wt} \%$, respectively. A 3D scaffold made of PCL and $30 \mathrm{wt} \%$ HA was designed by Shor $e$ t al. with improved mechanical properties and enhanced bioactivity [214]. The melt blending method was used for the fabrication of PCL/HA composites, and precision extrusion deposition system was developed at Drexel University to fabricate a scaffold with porosities from $60 \%$ to $70 \%$ and pore sizes from 450 to $750 \mu \mathrm{m}$. Another study was used to investigate the feasibility of producing highly porous PCL/BG composite via solid-liquid phase separation method for bone tissue engineering [215]. A porous scaffold with the porosity of $88 \%-92 \%$ and the highest elastic modulus of $251 \pm 32 \mathrm{kPa}$ was constructed using either dimethyl carbonate or dioxane as a solvent, and ethanol as an extracting medium. Additionally, the in vitro mineralization in SBF solution four weeks post incubation showed the role of BG particles in the development of apatite.

More recently, a 56-week experiment was conducted to assess the effect of degradation of PCL and its composite after the addition of $5 \mathrm{wt} \%$ bioactive glass on the $\mathrm{pH}$ of the media [201]. After a sudden increase to 8.36 in $\mathrm{pH}$ after the first week of the composite, the $\mathrm{pH}$ decreased; however, the $\mathrm{pH}$ of the pure PCL medium remained acidic with a drop from 6.5 to 5.1 until eight weeks. The $\mathrm{pH}$ values for all the samples slowly increased and ultimately approached a plateau; near 6 for PCL and 8.3 for the composite after the 14th week. The results underlined that the addition of ceramic fillers can eventually neutralize the acidic degradation of polyesters; however, there is no guarantee to keeping the $\mathrm{pH}$ neutral which is favorable for cell response.
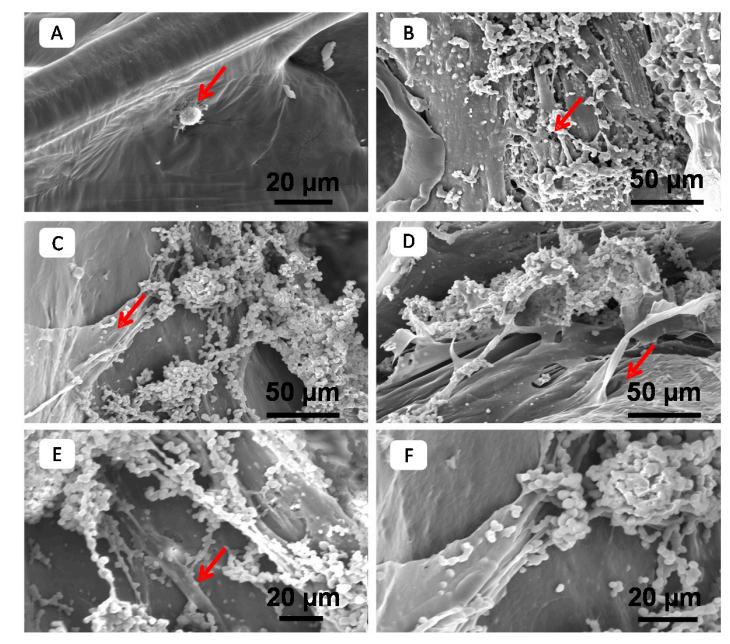

Figure 3. Images of cells cultured on (a) PCL scaffold; and (b-f) PCL/elastin composites. Top surfaces are shown in (a) and (c), cross sections in (b) and (d-f), arrowheads in the images show representative cells $50 \mathrm{mg} / \mathrm{mL}$ elastin solution was used to form composites. Figure reproduced from [209], with permission from Elsevier. 
Similar to all the other polyesters, there has been a major shift towards the chemical modification of PCL to finely tune the physicochemical properties of the polymer. The chemical copolymerization of caprolactone with functionalized monomers such as lactide [216], ethylene glycol [217-220], monomethyoxy poly(ethylene glycol) [221], acryloxy [222-224], and propylene fumarate [225] is used to form a new class of PCL-based polymers. In these chemical modification approaches, the ring opening polymerization technique is used to copolymerize the building monomer of PCL (caprolactone) with different monomers to ultimately alter the physicochemical properties of the resulting polymers. For instance, the multi-block copolymerization of PCL and PEG introduce the thermo-sensitive hydrogel with a promising gel strength and a controllable degradation profile [226]. Interestingly, the sequence of the constructive blocks has a significant impact on the mechanical properties and degradation profile of these copolymers [226]. A block copolymerization of MPEG and PCL was another example of an injectable hydrogel with proper gel strength [221]. Furthermore, an ocular delivery implant was recently developed by Peng et al. based on a PEG-PCL-PEG copolymer [227]. The thermo-responsive injectable hydrogel, loaded with bevacizumal, displayed neither corneal abnormalities nor any other ocular tissue damage, and was absorbed completely after three weeks as it is shown in Figure 4. Furthermore, Suen et al. has developed a block copolymer of PEG and PCL nanoparticles loaded with triamcinolone acetonide by nano precipitation to treat age-related macular degeneration [228]. The drug was successfully released from the nano career for up to four weeks at a $\mathrm{pH}$ of 7.4. This nano-based drug delivery vehicle shows promising results to replace the current intravitreal injection treatment.

Post-polymerization can be also conducted in order to modify biodegradable polyesters chemically. To this end, abstraction of protons from the polyester by treatment with a base, such as lithium diisopropyl amide, followed by subsequent addition of an electrophilic reagent, such as a halogen- or a carbonyl-containing compound, is a feasible method [21]. For instance, different pendant amine [229], hydroxyl, carboxyl groups [230], and peptides [231] have been used to functionalize the PCL backbone. $\mathrm{Hu}$ et al. utilized a chemical vapor deposition polymerization technique to functionalize the surface of PCL by poly[(4-amino-p-xylylene)-co-(p-xylene)]. The functionalized surface was coated by biotin to enhance the cell proliferation on the surface of PCL that resulted in 10-fold higher fibroblast cell ingrowth on the surface of scaffold [229].

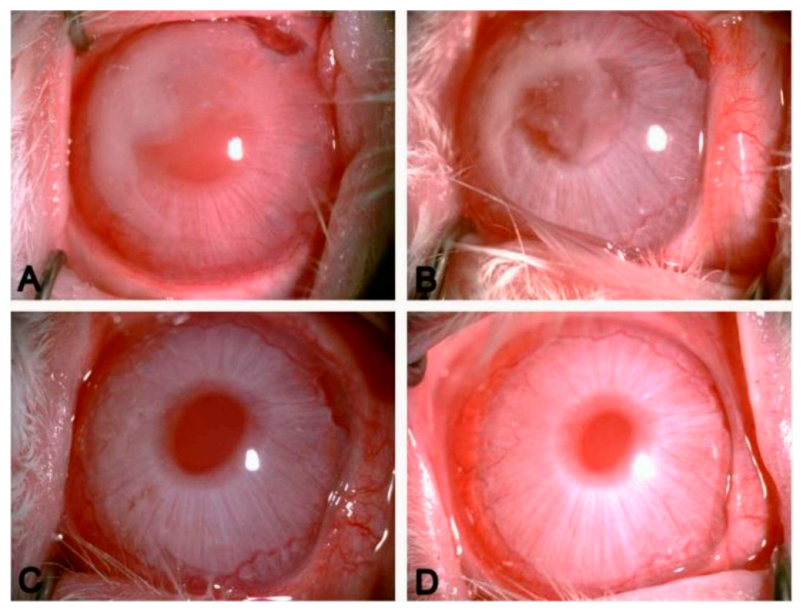

Figure 4. In vivo gel formation of PECE hydrogel in the anterior chamber of rabbit. PECE was absorbed completely within three weeks. (A) 1 day after injection; (B) 7 days after injection; (C) 14 days after injection; (D) 21 days after injection ( $\times 40$ magnification) [227].

PCL is deemed to have the highest potential among polyesters for the development of novel, commercial medical devices. This potential is attributed to the unique physicochemical properties of 
PCL, the relatively biologically benign biodegradation behavior of this polymer and the possibility for fine-tuning and making extensive chemical modifications.

\section{6. $P P F$}

Poly(propylene fumarate) (PPF) is a crosslinkable polyester with a wide application in in situ tissue engineering [232-234]. The presence of unsaturated carbon-carbon bonds in the backbone of PPF provides a unique property to form a crosslinked structure [235]. Despite the fabrication of self-crosslinked PPF [236,237], a variety of injectable solutions of PPF-based networks have been developed in the presence of poly(ethylene glycol)-dimethacrylate [238], PPF-diacrylate [239-241], and diethyl fumarate [242] as a crosslinking agent. The physicochemical properties and mechanical strength of the crosslinked PPF networks are predominantly dependent on the molecular weight and the polydispersity of PPF [243], the molecular characteristics of the crosslinking agent [244,245], and the ratio of the constituent materials [246]. Accordingly, different biodegradable scaffolds with an extensive range of properties were fabricated for specific applications including bone [247], ear [248], and nerve [249] tissue engineering.

In line with other polymers, the design of monomeric units is a standard approach for modifying the material characteristics of PPF. For instance, different synthetic and naturally driven macromers were incorporated into the propylene fumarate units to extend its biomedical application. The biosynthetic hydrogel, for example, was developed from alginate-PPF copolymer to form a biocompatible scaffold for cardiac tissue engineering [250,251]. Synthetic macromers such as polyethylene glycol (PEG) [252-256] and polyhedral oligomeric silsesquioxane [257], are also copolymerized with PPF to enhance their mechanical properties as well as promoting their biological performance.

\section{Conclusions}

Polyesters are biocompatible and biodegradable polymers that are broadly used for different medical applications as inert medical meshes, physical fixation supports or drug delivery vehicles. To extend the application of these polyesters to regenerative medicine and tissue engineering, it is necessary to modify them to acquire more hydrophilic and cell-interactive polymers. To this end, a series of physical and chemical modification approaches to different polyesters have been used. Among all polyesters, it is deemed that PLA and PCL have the highest potential for future application in medical devices due to their unique physicochemical properties. In addition, the commercial application of PPC and PHB may also be driven by environmental concerns as these two polymers are synthesized from renewable sources. Furthermore, chemical modification of polyesters is considered more favorable than physical modification as it can be scaled up in a more reproducible manner. Different modifications of polyesters in the future may lead to the production of a novel class of polymers on a commercial scale that are more processable, soluble in aqueous based solutions, more biologically active and display variable physicochemical properties.

Acknowledgment: The authors acknowledge the financial support of Australian Research Council (ARC). IM also acknowledges the financial supports from the Sydney University for the postgraduate scholarship.

Author Contributions: Sean Daly contributed in the preparation of the Section 3.2 and the abstract. Ali Negahi Shirazi wrote the chemical modification parts of the Section 4, and also Hesham Badr prepared the Section 3.3. The rest of the information and sections were studied and written by Iman Manavitehrani and edited by Ali Fathi. Fariba Dehghani contributed in leading the team, structuring this review paper and editing.

Conflicts of Interest: The authors declare no conflict of interest. 


\section{Abbreviations}

The following abbreviations are used in this manuscript:

$\begin{array}{ll}\text { PLA } & \text { Poly(lactic acid) } \\ \text { PLGA } & \text { Poly(lactic-co-glycolic acid) } \\ \text { PCL } & \text { Poly(E-caprolactone) } \\ \text { PHB } & \text { Poly(3-hydroxybutyrate) or Poly( } \beta \text {-hydroxybutyric acid) } \\ \text { PHBV } & \text { Poly(3-hydroxybutyrate-co-3-hydroxyvalerate) } \\ \text { PPC } & \text { Poly(propylene carbonate) } \\ \text { PBS } & \text { Poly(butylene succinate) } \\ \text { PPF } & \text { Poly(propylene fumarate) } \\ \text { TPU } & \text { Thermoplastic polyurethane } \\ \text { Y-M } & \text { Young's modulus } \\ \text { T-S } & \text { Tensile strength } \\ \text { C-S } & \text { compressive strength } \\ \text { R } & \text { resistance } \\ \text { E-M } & \text { Elastic modulus } \\ \text { S } & \text { stiffness } \\ \text { T-M } & \text { Tensile modulus } \\ \text { C-M } & \text { Compressive modulus } \\ \text { S-M } & \text { storage modulus } \\ \text { PHAs } & \text { Polyhydroxyalkanoates } \\ \text { PEO } & \text { Polyethylene oxide } \\ \text { PEGM } & \text { Polyethylene glycol methacrylate } \\ \text { CO } & \text { Carbon dioxide } \\ \text { GO } & \text { Graphene oxide } \\ \text { NIPU } & \text { Non-isocyanate polyurethane } \\ \text { HA } & \text { Hydroxyapatite } \\ \text { TCP } & \beta \text {-tricalcium phosphates } \\ \text { MWCNTs } & \text { Multiwall carbon nanotubes } \\ \text { BG } & \text { Bioglass } \\ \text { PLEOF } & \text { Poly(lactide-ethylene oxide fumarate) } \\ \text { HEMA } & \text { Hydroxyethyl methacrylate } \\ \text { PEG } & \text { Polyethylene glycol } \\ & \end{array}$

\section{References}

1. Research and Markets: Tissue Engineering: Technologies and Therapeutic Areas-A Global Market Overview to 2022. Available online: http://www.businesswire.com/news/home/20150915005908/en/ Research-Markets-Tissue-Engineering-Technologies-Therapeutic-Areas (accessed on 19 November 2015).

2. Ratner, B.D.; Hoffman, A.S.; Schoen, F.J.; Lemons, J.E. Introduction-biomaterials science: An evolving, multidisciplinary endeavor. In Biomaterials Science, 3rd ed.; Lemons, B.D., Ratner, A.S., Hoffman, F.J., Schoen, J.E., Eds.; Academic Press: Boston, MA, USA, 2013.

3. Sin, L.T.; Rahmat, A.R.; Rahman, W.A.W.A. 3-Applications of poly(lactic acid). In Handbook of Biopolymers and Biodegradable Plastics; Ebnesajjad, S., Ed.; William Andrew Publishing: Boston, MA, USA, 2013; pp. 55-69.

4. Diaz, A.; Katsarava, R.; Puiggali, J. Synthesis, properties and applications of biodegradable polymers derived from diols and dicarboxylic acids: From polyesters to poly(ester amide)s. Int. J Mol. Sci. 2014, 15, 7064-7123. [CrossRef] [PubMed] 
5. Sokolsky-Papkov, M.; Agashi, K.; Olaye, A.; Shakesheff, K.; Domb, A.J. Polymer carriers for drug delivery in tissue engineering. Adv. Drug Deliv. Rev. 2007, 59, 187-206. [CrossRef] [PubMed]

6. Nazemi, K.; Azadpour, P.; Moztarzadeh, F.; Urbanska, A.M.; Mozafari, M. Tissue-engineered chitosan/bioactive glass bone scaffolds integrated with PLGA nanoparticles: A therapeutic design for on-demand drug delivery. Mater. Lett. 2015, 138, 16-20. [CrossRef]

7. Makadia, H.K.; Siegel, S.J. Poly lactic-co-glycolic acid (PLGA) as biodegradable controlled drug delivery carrier. Polymers 2011, 3, 1377-1397. [CrossRef] [PubMed]

8. Seyednejad, H.; Gawlitta, D.; Dhert, W.J.A.; van Nostrum, C.F.; Vermonden, T.; Hennink, W.E. Preparation and characterization of a three-dimensional printed scaffold based on a functionalized polyester for bone tissue engineering applications. Acta Biomater. 2011, 7, 1999-2006. [CrossRef] [PubMed]

9. Kretlow, J.D.; Klouda, L.; Mikos, A.G. Injectable matrices and scaffolds for drug delivery in tissue engineering. Adv. Drug Deliv. Rev. 2007, 59, 263-273. [CrossRef] [PubMed]

10. Woodruff, M.A.; Hutmacher, D.W. The return of a forgotten polymer-polycaprolactone in the 21st century. Progress Polym. Sci. 2010, 35, 1217-1256. [CrossRef]

11. Cameron, D.J.A.; Shaver, M.P. Aliphatic polyester polymer stars: Synthesis, properties and applications in biomedicine and nanotechnology. Chem. Soc. Rev. 2011, 40, 1761-1776. [CrossRef] [PubMed]

12. Amass, W.; Amass, A.; Tighe, B. A review of biodegradable polymers: Uses, current developments in the synthesis and characterization of biodegradable polyesters, blends of biodegradable polymers and recent advances in biodegradation studies. Polym. Int. 1998, 47, 89-144. [CrossRef]

13. Angela, L.S.; Chia-Chih, C.; Bryan, P.; Todd, E. Strategies in aliphatic polyester synthesis for biomaterial and drug delivery applications. In Degradable Polymers and Materials: Principles and Practice, 2nd ed.; American Chemical Society: Washington, DC, USA, 2012; Volume 1114, pp. 237-254.

14. Yu, Y.; Wu, D.; Liu, C.; Zhao, Z.; Yang, Y.; Li, Q. Lipase/esterase-catalyzed synthesis of aliphatic polyesters via polycondensation: A review. Process Biochem. 2012, 47, 1027-1036. [CrossRef]

15. Paul, S.; Zhu, Y.; Romain, C.; Brooks, R.; Saini, P.K.; Williams, C.K. Ring-opening copolymerization (ROCOP): Synthesis and properties of polyesters and polycarbonates. Chem. Commun. 2015, 51, 6459-6479. [CrossRef] [PubMed]

16. Zhong, X.; Dehghani, F. Solvent free synthesis of organometallic catalysts for the copolymerisation of carbon dioxide and propylene oxide. Appl. Catal. B Environ. 2010, 98, 101-111. [CrossRef]

17. Masutani, K.; Kimura, Y. Chapter 1 PLA synthesis. From the monomer to the polymer. In Poly(lactic acid) Science and Technology: Processing, Properties, Additives and Applications; The Royal Society of Chemistry: London, UK, 2015; pp. 1-36.

18. Lasprilla, A.J.R.; Martinez, G.A.R.; Lunelli, B.H.; Jardini, A.L.; Filho, R.M. Poly-lactic acid synthesis for application in biomedical devices-A review. Biotechnol. Adv. 2012, 30, 321-328. [CrossRef] [PubMed]

19. Verlinden, R.A.J.; Hill, D.J.; Kenward, M.A.; Williams, C.D.; Radecka, I. Bacterial synthesis of biodegradable polyhydroxyalkanoates. J. Appl. Microbiol. 2007, 102, 1437-1449. [CrossRef] [PubMed]

20. Williams, S.F.; Martin, D.P. Applications of polyhydroxyalkanoates (PHA) in medicine and pharmacy. In Biopolymers Online; Wiley-VCH Verlag GmbH \& Co. KGaA: Weinheim, Germany, 2005.

21. Seyednejad, H.; Ghassemi, A.H.; van Nostrum, C.F.; Vermonden, T.; Hennink, W.E. Functional aliphatic polyesters for biomedical and pharmaceutical applications. J. Control. Release 2011, 152, 168-176. [CrossRef] [PubMed]

22. Armentano, I.; Dottori, M.; Fortunati, E.; Mattioli, S.; Kenny, J.M. Biodegradable polymer matrix nanocomposites for tissue engineering: A review. Polym. Degrad. Stab. 2010, 95, 2126-2146. [CrossRef]

23. Saini, M.; Singh, Y.; Arora, P.; Arora, V.; Jain, K. Implant biomaterials: A comprehensive review. World J. Clin. Cases WJCC 2015, 3, 52-57. [CrossRef] [PubMed]

24. Røhl, L.; Larsen, E.; Linde, F.; Odgaard, A.; Jørgensen, J. Tensile and compressive properties of cancellous bone. J. Biomech. 1991, 24, 1143-1149. [CrossRef]

25. Little, C.J.; Bawolin, N.K.; Chen, X. Mechanical properties of natural cartilage and tissue-engineered constructs. Tissue Eng. Rev. 2011, 17, 213-227. [CrossRef] [PubMed]

26. Ebrahimi, A.P. Mechanical properties of normal and diseased cerebrovascular system. J. Vasc. Int. Neurol. 2009, 2, 155-162.

27. Salahshoor, M.; Guo, Y. Biodegradable orthopedic magnesium-calcium (MGCA) alloys, processing, and corrosion performance. Materials 2012, 5, 135. [CrossRef] 
28. Haghighat, F.; Ravandi, S. Mechanical properties and in vitro degradation of PLGA suture manufactured via electrospinning. Fibers Polym. 2014, 15, 71-77. [CrossRef]

29. Pott, P.P.; Schwarz, M.L.R.; Gundling, R.; Nowak, K.; Hohenberger, P.; Roessner, E.D. Mechanical properties of mesh materials used for hernia repair and soft tissue augmentation. PLoS ONE 2012, 7, e46978. [CrossRef] [PubMed]

30. Jamshidian, M.; Tehrany, E.A.; Imran, M.; Jacquot, M.; Desobry, S. Poly-lactic acid: Production, applications, nanocomposites, and release studies. Compr. Rev. Food Sci. Food Saf. 2010, 9, 552-571. [CrossRef]

31. Middleton, J.C.; Tipton, A.J. Synthetic biodegradable polymers as orthopedic devices. Biomaterials 2000, 21, 2335-2346. [CrossRef]

32. Gentile, P.; Chiono, V.; Carmagnola, I.; Hatton, P.V. An overview of poly(lactic-co-glycolic) acid (PLGA)-based biomaterials for bone tissue engineering. Int. J. Mol. Sci. 2014, 15, 3640-3659. [CrossRef] [PubMed]

33. Sin, L.T.; Rahmat, A.R.; Rahman, W.A.W.A. 2-overview of poly(lactic acid). In Handbook of Biopolymers and Biodegradable Plastics; Ebnesajjad, S., Ed.; William Andrew Publishing: Boston, MD, USA, 2013; pp. 11-54.

34. Jiang, L.; Zhang, J. 6-Biodegradable polymers and polymer blends. In Handbook of Biopolymers and Biodegradable Plastics; Ebnesajjad, S., Ed.; William Andrew Publishing: Boston, MD, USA, 2013; pp. 109-128.

35. Shi, X.F.; Hudson, J.L.; Spicer, P.P.; Tour, J.M.; Krishnamoorti, R.; Mikos, A.G. Rheological behaviour and mechanical characterization of injectable poly(propylene fumarate)/single-walled carbon nanotube composites for bone tissue engineering. Nanotechnology 2005, 16, S531-S538. [CrossRef] [PubMed]

36. Gao, Q.; Hu, B.; Ning, Q.; Ye, C.; Xie, J.; Ye, J.; Gao, C. A primary study of poly(propylene fumarate)-2-hydroxyethyl methacrylate copolymer scaffolds for tarsal plate repair and reconstruction in rabbit eyelids. J. Mater. Chem. B 2015, 3, 4052-4062. [CrossRef]

37. Du, L.; Qu, B.; Meng, Y.; Zhu, Q. Structural characterization and thermal and mechanical properties of poly(propylene carbonate)/MGAL-LDH exfoliation nanocomposite via solution intercalation. Compos. Sci. Technol. 2006, 66, 913-918. [CrossRef]

38. Liu, L.; Yu, J.; Cheng, L.; Qu, W. Mechanical properties of poly(butylene succinate) (PBS) biocomposites reinforced with surface modified jute fibre. Compos. Appl. Sci. Manuf. 2009, 40, 669-674. [CrossRef]

39. Contiliano, J.H.; Yuan, J.J.; Tenhuisen, K.S. Polymer-Based Orthopedic Screw and Driver System with Increased Insertion Torque Tolerance and Associated Method for Making and Using Same. U.S. Patents US20050216016 A1, 29 September 2005.

40. Schwach, G.; Vert, M. In vitro and in vivo degradation of lactic acid-based interference screws used in cruciate ligament reconstruction. Int. J. Biol. Macromol. 1999, 25, 283-291. [CrossRef]

41. Tenhuisen, K.S.; Janas, V.F.; Cooper, K.L.; Overaker, D.W.; Yuan, J.J. Self-Tapping Resorbable Two-Piece Bone Screw. U.S. Patents US6916321 B2, 12 July 2005.

42. Herrmann, J.B.; Kelly, R.J.; Higgins, G.A. Polyglycolic acid sutures: Laboratory and clinical evaluation of a new absorbable suture material. Arch. Surg. 1970, 100, 486-490. [CrossRef] [PubMed]

43. Nair, L.S.; Laurencin, C.T. Biodegradable polymers as biomaterials. Progress Polym. Sci. 2007, 32, 762-798. [CrossRef]

44. Wilkerson, J.P.; Zvijac, J.E.; Uribe, J.W.; Schurhoff, M.R.; Green, J.B. Failure of polymerized lactic acid tacks in shoulder surgery. J. Shoulder Elb. Surg. 2003, 12, 117-121. [CrossRef] [PubMed]

45. Liggins, R.T.; Burt, H.M. Paclitaxel loaded poly(L-lactic acid) microspheres: Properties of microspheres made with low molecular weight polymers. Int. J. Pharm. 2001, 222, 19-33. [CrossRef]

46. Park, T.G. Degradation of poly(D,L-lactic acid) microspheres: effect of molecular weight. J. Control. Release 1994, 30, 161-173. [CrossRef]

47. Alexis, F. Factors affecting the degradation and drug-release mechanism of poly(lactic acid) and poly[(lactic acid)-co-(glycolic acid)]. Polym. Int. 2005, 54, 36-46. [CrossRef]

48. Tsuji, H.; Mizuno, A.; Ikada, Y. Properties and morphology of poly(L-lactide). III. Effects of initial crystallinity on long-term in vitro hydrolysis of high molecular weight poly(L-lactide) film in phosphate-buffered solution. J. Appl. Polym. Sci. 2000, 77, 1452-1464. [CrossRef]

49. Schliecker, G.; Schmidt, C.; Fuchs, S.; Wombacher, R.; Kissel, T. Hydrolytic degradation of poly(lactide-co-glycolide) films: Effect of oligomers on degradation rate and crystallinity. Int. J. Pharm. 2003, 266, 39-49. [CrossRef] 
50. Lee, J.W.; Gardella, J.A. In vitro hydrolytic surface degradation of poly(glycolic acid): Role of the surface segregated amorphous region in the induction period of bulk erosion. Macromolecules 2001, 34, 3928-3937. [CrossRef]

51. Pitt, C.G.; Chasalow, F.I.; Hibionada, Y.M.; Klimas, D.M.; Schindler, A. Aliphatic polyesters. I. The degradation of poly(e-caprolactone) in vivo. J. Appl. Polym. Sci. 1981, 26, 3779-3787. [CrossRef]

52. Castilla-Cortázar, I.; Más-Estellés, J.; Meseguer-Dueñas, J.M.; Escobar Ivirico, J.L.; Marí, B.; Vidaurre, A. Hydrolytic and enzymatic degradation of a poly(e-caprolactone) network. Polym. Degrad. Stab. 2012, 97, 1241-1248. [CrossRef]

53. Fukuzaki, H.; Yoshida, M.; Asano, M.; Kumakura, M.; Mashimo, T.; Yuasa, H.; Imai, K.; Hidetoshi, Y. Synthesis of low-molecular-weight copoly(L-lactic acid/ $\varepsilon$-caprolactone) by direct copolycondensation in the absence of catalysts, and enzymatic degradation of the polymers. Polymer 1990, 31, 2006-2014. [CrossRef]

54. Gan, Z.; Liang, Q.; Zhang, J.; Jing, X. Enzymatic degradation of poly( $\varepsilon$-caprolactone) film in phosphate buffer solution containing lipases. Polym. Degrad. Stab. 1997, 56, 209-213. [CrossRef]

55. Gan, Z.; Yu, D.; Zhong, Z.; Liang, Q.; Jing, X. Enzymatic degradation of poly(E-caprolactone)/poly(DL-lactide) blends in phosphate buffer solution. Polymer 1999, 40, 2859-2862. [CrossRef]

56. Grizzi, I.; Garreau, H.; Li, S.; Vert, M. Hydrolytic degradation of devices based on poly(DL-lactic acid) size-dependence. Biomaterials 1995, 16, 305-311. [CrossRef]

57. Ding, Z.; Liu, Z.; Wei, W.; Li, Z. Preparation and characterization of PLLA composite scaffolds by $\mathrm{ScCO}_{2}$-induced phase separation. Polym. Compos. 2012, 33, 1667-1671. [CrossRef]

58. Danmark, S.; Finne-Wistrand, A.; Schander, K.; Hakkarainen, M.; Arvidson, K.; Mustafa, K.; Albertsson, A.C. In vitro and in vivo degradation profile of aliphatic polyesters subjected to electron beam sterilization. Acta Biomater. 2011, 7, 2035-2046. [CrossRef] [PubMed]

59. Sui, G.; Yang, X.; Mei, F.; Hu, X.; Chen, G.; Deng, X.; Ryu, S. Poly-L-lactic acid/hydroxyapatite hybrid membrane for bone tissue regeneration. J. Biomed. Mater. Res. 2007, 82A, 445-454. [CrossRef] [PubMed]

60. Wang, C.; Chang, T.; Yang, H.; Cui, M. Surface physiological changes induced by lactic acid on pathogens in consideration of $\mathrm{pKa}$ and $\mathrm{pH}$. Food Control 2014, 46, 525-531. [CrossRef]

61. Volova, T.G. Polyhydroxyalkanoates_Plastic Materials of the 21st Century: Production, Properties, Applications; Nova Science Publishers: New York, NY, USA, 2004.

62. Ikada, Y.; Tsuji, H. Biodegradable polyesters for medical and ecological applications. Macromol. Rapid Commun. 2000, 21, 117-132. [CrossRef]

63. Mainil-Varlet, P.; Curtis, R.; Gogolewski, S. Effect of in vivo and in vitro degradation on molecular and mechanical properties of various low-molecular-weight polylactides. J. Biomed. Mater. Res. 1997, 36, 360-380. [CrossRef]

64. Pietrzak, W.S.; Sarver, D.R.; Verstynen, M.L. Bioabsorbable polymer science for the practicing surgeon. J. Craniofacial Surg. 1997, 8, 87-91. [CrossRef]

65. El Mubarak, M.A.S.; Lamari, F.N.; Kontoyannis, C. Simultaneous determination of allantoin and glycolic acid in snail mucus and cosmetic creams with high performance liquid chromatography and ultraviolet detection. J. Chromatogr. A 2013, 1322, 49-53. [CrossRef] [PubMed]

66. McBane, J.E.; Sharifpoor, S.; Cai, K.; Labow, R.S.; Santerre, J.P. Biodegradation and in vivo biocompatibility of a degradable, polar/hydrophobic/ionic polyurethane for tissue engineering applications. Biomaterials 2011, 32, 6034-6044. [CrossRef] [PubMed]

67. Tao, J.; Song, C.; Cao, M.; Hu, D.; Liu, L.; Liu, N.; Wang, S. Thermal properties and degradability of poly(propylene carbonate)/poly( $\beta$-hydroxybutyrate-co- $\beta$-hydroxyvalerate) (PPC/PHBV) blends. Polym. Degrad. Stab. 2009, 94, 575-583. [CrossRef]

68. Jayachandran, J.P.; Reed, H.A.; Hongshi, Z.; Rhodes, L.F.; Henderson, C.L.; Allen, S.; Kohl, P.A. Air-channel fabrication for microelectromechanical systems via sacrificial photosensitive polycarbonates. Microelectromech. Syst. J. 2003, 12, 147-159. [CrossRef]

69. Luinstra, G.A.; Borchardt, E. Material properties of poly (propylene carbonates). In Synthetic Biodegradable Polymers; Springer: Berlin, Germany, 2012; pp. 29-48.

70. He, J.; Chen, S.; Yu, Z. Determination of poly- $\beta$-hydroxybutyric acid in bacillus thuringiensis by capillary zone electrophoresis with indirect ultraviolet absorbance detection. J. Chromatogr. A 2002, 973, 197-202. [CrossRef] 
71. Dahl, S.R.; Olsen, K.M.; Strand, D.H. Determination of $\gamma$-hydroxybutyrate (GHB), $\beta$-hydroxybutyrate (BHB), pregabalin, 1,4-butane-diol (1,4BD) and $\gamma$-butyrolactone (GBL) in whole blood and urine samples by UPLC-MSMS. J. Chromatogr. B 2012, 885-886, 37-42. [CrossRef] [PubMed]

72. Kunze, C.; Edgar Bernd, H.; Androsch, R.; Nischan, C.; Freier, T.; Kramer, S.; Kramp, B.; Schmitz, K.-P. In vitro and in vivo studies on blends of isotactic and atactic poly(3-hydroxybutyrate) for development of a dura substitute material. Biomaterials 2006, 27, 192-201. [CrossRef] [PubMed]

73. Volova, T.; Shishatskaya, E.; Sevastianov, V.; Efremov, S.; Mogilnaya, O. Results of biomedical investigations of PHB and PHB/PHV fibers. Biochem. Eng. J. 2003, 16, 125-133. [CrossRef]

74. Boskhomdzhiev, A.P.; Bonartsev, A.P.; Makhina, T.K.; Myshkina, V.L.; Ivanov, E.A.; Bagrov, D.V.; Filatova, E.V.; Iordanskii, A.L.; Bonartseva, G.A. Biodegradation kinetics of poly(3-hydroxybutyrate)-based biopolymer systems. Biochem. Suppl. Series B Biomed. Chem. 2010, 4, 177-183. [CrossRef]

75. Bonartsev, A.; Myshkina, V.; Nikolaeva, D.; Furina, E.; Makhina, T.; Livshits, V.; Boskhomdzhiev, A.; Ivanov, E.; Iordanskii, A.; Bonartseva, G. Biosynthesis, biodegradation, and application of poly (3-hydroxybutyrate) and its copolymers-natural polyesters produced by diazotrophic bacteria. Commun. Curr. Res. Educ. Top. Trends Appl. Microbiol. 2007, 1, 295-307.

76. Lindström, A.; Albertsson, A.-C.; Hakkarainen, M. Quantitative determination of degradation products an effective means to study early stages of degradation in linear and branched poly(butylene adipate) and poly(butylene succinate). Polym. Degrad. Stab. 2004, 83, 487-493. [CrossRef]

77. Ding, M.; Zhang, M.; Yang, J.; Qiu, J.-H. Study on the enzymatic degradation of PBS and its alcohol acid modified copolymer. Biodegradation 2012, 23, 127-132. [CrossRef] [PubMed]

78. Díaz, E.; Sandonis, I.; Valle, M.B. In vitro degradation of poly(caprolactone)/nHA composites. J. Nanomater. 2014, 2014, 8. [CrossRef]

79. Lam, C.X.F.; Hutmacher, D.W.; Schantz, J.-T.; Woodruff, M.A.; Teoh, S.H. Evaluation of polycaprolactone scaffold degradation for 6 months in vitro and in vivo. J. Biomed. Mater. Res. 2009, 90A, 906-919. [CrossRef] [PubMed]

80. Timmer, M.D.; Shin, H.; Horch, R.A.; Ambrose, C.G.; Mikos, A.G. In vitro cytotoxicity of injectable and biodegradable poly(propylene fumarate)-based networks: Unreacted macromers, cross-linked networks, and degradation products. Biomacromolecules 2003, 4, 1026-1033. [CrossRef] [PubMed]

81. Manavitehrani, I.; Fathi, A.; Wang, Y.; Maitz, P.K.; Dehghani, F. Reinforced poly(propylene carbonate) composite with enhanced and tunable characteristics, an alternative for poly(lactic acid). ACS Appl. Mater. Interfaces 2015, 7, 22421-22430. [CrossRef] [PubMed]

82. Eggers, J.; Steinbüchel, A. Poly(3-hydroxybutyrate) degradation in ralstonia eutropha h16 is mediated stereoselectively to (s)-3-hydroxybutyryl coenzyme a (CoA) via crotonyl-CoA. J. Bacteriol. 2013, 195, 3213-3223. [CrossRef] [PubMed]

83. Ulery, B.D.; Nair, L.S.; Laurencin, C.T. Biomedical applications of biodegradable polymers. J. Polym. Sci. Polym. Phys. 2011, 49, 832-864. [CrossRef] [PubMed]

84. Niaounakis, M. 7-Medical, dental, and pharmaceutical applications. In Biopolymers: Applications and Trends; Niaounakis, M., Ed.; William Andrew Publishing: Oxford, UK, 2015; pp. 291-405.

85. Doğan, A.; Demirci, S.; Bayir, Y.; Halici, Z.; Karakus, E.; Aydin, A.; Cadirci, E.; Albayrak, A.; Demirci, E.; Karaman, A.; et al. Boron containing poly-(lactide-co-glycolide) (PLGA) scaffolds for bone tissue engineering. Mater. Sci. Eng. C 2014, 44, 246-253. [CrossRef] [PubMed]

86. Chuenjitkuntaworn, B.; Supaphol, P.; Pavasant, P.; Damrongsri, D. Electrospun poly(L-lactic acid)/hydroxyapatite composite fibrous scaffolds for bone tissue engineering. Polym. Int. 2010, 59, 227-235. [CrossRef]

87. Zhao, J.H.; Han, W.Q.; Chen, H.D.; Tu, M.; Huan, S.W.; Miao, G.Q.; Zeng, R.; Wu, H.; Cha, Z.G.; Zhou, C.R. Fabrication and in vivo osteogenesis of biomimetic poly(propylene carbonate) scaffold with nanofibrous chitosan network in macropores for bone tissue engineering. J. Mater. Sci. Mater. Med. 2012, 23, 517-525. [CrossRef] [PubMed]

88. Jing, X.; Salick, M.R.; Cordie, T.; Mi, H.-Y.; Peng, X.-F.; Turng, L.-S. Electrospinning homogeneous nanofibrous poly(propylene carbonate)/gelatin composite scaffolds for tissue engineering. Ind. Eng. Chem. Res. 2014, 53, 9391-9400. [CrossRef] 
89. Li, H.-Y.; Li, H.; Wang, B.-J.; Gu, Q.; Jiang, Z.-Q.; Wu, X.-D. Synthesis and properties of poly(3-hydroxybutyrate-co-3-hydroxyvalerate)/chitin nanocrystals composite scaffolds for tissue engineering. Chin. Chem. Lett. 2014, 25, 1635-1638. [CrossRef]

90. Nair, M.B.; Baranwal, G.; Vijayan, P.; Keyan, K.S.; Jayakumar, R. Composite hydrogel of chitosan-poly(hydroxybutyrate-co-valerate) with chondroitin sulfate nanoparticles for nucleus pulposus tissue engineering. Coll. Surf. B Biointerfaces 2015, 136, 84-92. [CrossRef] [PubMed]

91. European Bioplastics, I.f.B., and Biocomposites, nova Institute. Global Production Capacities of Bioplastics. Available online: http://en.european-bioplastics.org/technologymaterials/materials/ (accessed on 27 September 2015).

92. Fambri, L.; Pegoretti, A.; Fenner, R.; Incardona, S.D.; Migliaresi, C. Biodegradable fibres of poly(L-lactic acid) produced by melt spinning. Polymer 1997, 38, 79-85. [CrossRef]

93. Wang, Q.; Bao, Y.; Ahire, J.; Chao, Y. Co-encapsulation of biodegradable nanoparticles with silicon quantum dots and quercetin for monitored delivery. Adv. Healthc. Mater. 2013, 2, 459-466. [CrossRef] [PubMed]

94. Avérous, L. 9-Synthesis, properties, environmental and biomedical applications of polylactic acid. In Handbook of Biopolymers and Biodegradable Plastics; Ebnesajjad, S., Ed.; William Andrew Publishing: Boston, MA, USA, 2013; pp. 171-188.

95. Martin, O.; Avérous, L. Poly(lactic acid): Plasticization and properties of biodegradable multiphase systems. Polymer 2001, 42, 6209-6219. [CrossRef]

96. Mi, H.-Y.; Salick, M.R.; Jing, X.; Jacques, B.R.; Crone, W.C.; Peng, X.-F.; Turng, L.-S. Characterization of thermoplastic polyurethane/polylactic acid (TPU/PLA) tissue engineering scaffolds fabricated by microcellular injection molding. Mater. Sci. Eng. C 2013, 33, 4767-4776. [CrossRef] [PubMed]

97. Kouya, T.; Tada, S.-i.; Minbu, H.; Nakajima, Y.; Horimizu, M.; Kawase, T.; Lloyd, D.R.; Tanaka, T. Microporous membranes of PLLA/PCL blends for periosteal tissue scaffold. Mater. Lett. 2013, 95, 103-106. [CrossRef]

98. Serra, T.; Ortiz-Hernandez, M.; Engel, E.; Planell, J.A.; Navarro, M. Relevance of PEG in PLA-based blends for tissue engineering 3D-printed scaffolds. Mater. Sci. Eng. C 2014, 38, 55-62. [CrossRef] [PubMed]

99. Davachi, S.M.; Kaffashi, B.; Zamanian, A.; Torabinejad, B.; Ziaeirad, Z. Investigating composite systems based on poly L-lactide and poly L-lactide/triclosan nanoparticles for tissue engineering and medical applications. Mater. Sci. Eng. C 2016, 58, 294-309. [CrossRef] [PubMed]

100. Tanase, C.E.; Spiridon, I. PLA/chitosan/keratin composites for biomedical applications. Mater. Sci. Eng. C 2014, 40, 242-247. [CrossRef] [PubMed]

101. Han, X.; Wang, D.; Chen, X.; Lin, H.; Qu, F. One-pot synthesis of macro-mesoporous bioactive glasses/polylactic acid for bone tissue engineering. Mater. Sci. Eng. C 2014, 43, 367-374. [CrossRef] [PubMed]

102. Le Bolay, N.; Santran, V.; Dechambre, G.; Combes, C.; Drouet, C.; Lamure, A.; Rey, C. Production, by co-grinding in a media mill, of porous biodegradable polylactic acid-apatite composite materials for bone tissue engineering. Powder Technol. 2009, 190, 89-94. [CrossRef]

103. Cai, X.; Tong, H.; Shen, X.; Chen, W.; Yan, J.; Hu, J. Preparation and characterization of homogeneous chitosan-polylactic acid/hydroxyapatite nanocomposite for bone tissue engineering and evaluation of its mechanical properties. Acta Biomater. 2009, 5, 2693-2703. [CrossRef] [PubMed]

104. Charles-Harris, M.; del Valle, S.; Hentges, E.; Bleuet, P.; Lacroix, D.; Planell, J.A. Mechanical and structural characterisation of completely degradable polylactic acid/calcium phosphate glass scaffolds. Biomaterials 2007, 28, 4429-4438. [CrossRef] [PubMed]

105. Dong, Y.; Marshall, J.; Haroosh, H.J.; Mohammadzadehmoghadam, S.; Liu, D.; Qi, X.; Lau, K.-T. Polylactic acid (PLA)/halloysite nanotube (HNT) composite mats: Influence of hnt content and modification. Compos. Appl. Sci. Manuf. 2015, 76, 28-36. [CrossRef]

106. Huang, W.; Shi, X.; Ren, L.; Du, C.; Wang, Y. PHBV microspheres-PLGA matrix composite scaffold for bone tissue engineering. Biomaterials 2010, 31, 4278-4285. [CrossRef] [PubMed]

107. Meng, Z.X.; Wang, Y.S.; Ma, C.; Zheng, W.; Li, L.; Zheng, Y.F. Electrospinning of PLGA/gelatin randomly-oriented and aligned nanofibers as potential scaffold in tissue engineering. Mater. Sci. Eng. C 2010, 30, 1204-1210. [CrossRef]

108. Qian, J.; Xu, W.; Yong, X.; Jin, X.; Zhang, W. Fabrication and in vitro biocompatibility of biomorphic PLGA/nHA composite scaffolds for bone tissue engineering. Mater. Sci. Eng. C 2014, 36, 95-101. [CrossRef] [PubMed] 
109. Boccaccini, A.R.; Blaker, J.J.; Maquet, V.; Day, R.M.; Jérôme, R. Preparation and characterisation of poly(lactide-co-glycolide) (PLGA) and PLGA/bioglass ${ }^{\circledR}$ composite tubular foam scaffolds for tissue engineering applications. Mater. Sci. Eng. C 2005, 25, 23-31. [CrossRef]

110. Mehrasa, M.; Asadollahi, M.A.; Ghaedi, K.; Salehi, H.; Arpanaei, A. Electrospun aligned PLGA and PLGA/gelatin nanofibers embedded with silica nanoparticles for tissue engineering. Int. J. Biol. Macromol. 2015, 79, 687-695. [CrossRef] [PubMed]

111. Dai, W.; Kawazoe, N.; Lin, X.; Dong, J.; Chen, G. The influence of structural design of PLGA/collagen hybrid scaffolds in cartilage tissue engineering. Biomaterials 2010, 31, 2141-2152. [CrossRef] [PubMed]

112. Chen, G.; Tanaka, J.; Tateishi, T. Osteochondral tissue engineering using a PLGA-collagen hybrid mesh. Mater. Sci. Eng. C 2006, 26, 124-129. [CrossRef]

113. Nojehdehian, H.; Moztarzadeh, F.; Baharvand, H.; Nazarian, H.; Tahriri, M. Preparation and surface characterization of poly-L-lysine-coated PLGA microsphere scaffolds containing retinoic acid for nerve tissue engineering: In vitro study. Coll. Surf. B Biointerfaces 2009, 73, 23-29. [CrossRef] [PubMed]

114. Persson, M.; Lorite, G.S.; Kokkonen, H.E.; Cho, S.-W.; Lehenkari, P.P.; Skrifvars, M.; Tuukkanen, J. Effect of bioactive extruded PLGA/HA composite films on focal adhesion formation of preosteoblastic cells. Coll. Surf. B Biointerfaces 2014, 121, 409-416. [CrossRef] [PubMed]

115. Cohen, A.J.; Dickerman, R.D.; Schneider, S.J. New method of pediatric cranioplasty for skull defect utilizing polylactic acid absorbable plates and carbonated apatite bone cement. J. Craniofac. Surg. 2004, 15, 469-472. [CrossRef] [PubMed]

116. Hasan, M.S.; Carpenter, N.; Wei, T.L.; McNally, D.; Ahmed, I.; Boszczyk, B.M. Effects of adding resorbable phosphate glass fibres and PLA to calcium phosphate bone cements. J. Appl. Biomater. Funct. Mater. 2014, 12, 203-209. [CrossRef] [PubMed]

117. Losee, J.E.; Karmacharya, J.; Gannon, F.H.; Slemp, A.E.; Ong, G.; Hunenko, O.; Gorden, A.D.; Bartlett, S.P.; Kirschner, R.E. Reconstruction of the immature craniofacial skeleton with a carbonated calcium phosphate bone cement: Interaction with bioresorbable mesh. J. Craniofacial Surg. 2003, 14, 117-124. [CrossRef]

118. Stupack, D.G.; Puente, X.S.; Boutsaboualoy, S.; Storgard, C.M.; Cheresh, D.A. Apoptosis of adherent cells by recruitment of caspase-8 to unligated integrins. J. Cell Biol. 2001, 155, 459-470. [CrossRef] [PubMed]

119. Lieb, E.; Hacker, M.; Tessmar, J.; Kunz-Schughart, L.A.; Fiedler, J.; Dahmen, C.; Hersel, U.; Kessler, H.; Schulz, M.B.; Gopferich, A. Mediating specific cell adhesion to low-adhesive diblock copolymers by instant modification with cyclic RGD peptides. Biomaterials 2005, 26, 2333-2341. [CrossRef] [PubMed]

120. Lyons, A.M.; Vasile, M.J.; Pearce, E.M.; Waszczak, J.V. Copper chloride complexes with poly(2-vinylpyridine): Preparation and redox properties. Macromolecules 1988, 21, 3125-3134. [CrossRef]

121. Lecomte, P.; Detrembleur, C.; Lou, X.; Mazza, M.; Halleux, O.; Jerome, R. Novel functionalization routes of poly(epsilon-caprolactone). Macromol. Symp. 2000, 157, 47-60. [CrossRef]

122. Lou, X.D.; Detrembleur, C.; Jerome, R. Novel aliphatic polyesters based on functional cyclic (di)esters. Macromol. Rapid Commun. 2003, 24, 161-172. [CrossRef]

123. Jerome, C.; Lecomte, P. Recent advances in the synthesis of aliphatic polyesters by ring-opening polymerization. Adv. Drug Deliv. Rev. 2008, 60, 1056-1076. [CrossRef] [PubMed]

124. Williams, C.K. Synthesis of functionalized biodegradable polyesters. Chem. Soc. Rev. 2007, 36, 1573-1580. [CrossRef] [PubMed]

125. Metters, A.T.; Anseth, K.S.; Bowman, C.N. Fundamental studies of a novel, biodegradable PEG-b-PLA hydrogel. Polymer 2000, 41, 3993-4004. [CrossRef]

126. Riley, T.; Stolnik, S.; Heald, C.R.; Xiong, C.D.; Garnett, M.C.; Illum, L.; Davis, S.S.; Purkiss, S.C.; Barlow, R.J.; Gellert, P.R. Physicochemical evaluation of nanoparticles assembled from poly(lactic acid)-poly(ethylene glycol) (PLA-PEG) block copolymers as drug delivery vehicles. Langmuir 2001, 17, 3168-3174. [CrossRef]

127. Fu, B.; Xiao, L.; Yu, L.J.; Yang, G. Preparation of lactic acid based polyurethanes modified by castor oil. Multi-Funct. Mater. Struct. 2008, 47-50, 1458-1461. [CrossRef]

128. Hu, Y.F.; Liu, Y.F.; Qi, X.; Liu, P.; Fan, Z.Y.; Li, S.M. Novel bioresorbable hydrogels prepared from chitosan-graft-polylactide copolymers. Polym. Int. 2012, 61, 74-81. [CrossRef]

129. Suyatma, N.E.; Copinet, A.; Legin-Copinet, E.; Fricoteaux, F.; Coma, V. Different PLA grafting techniques on chitosan. J. Polym. Environ. 2011, 19, 166-171. [CrossRef] 
130. Temenoff, J.S.; Park, H.; Jabbari, E.; Conway, D.E.; Sheffield, T.L.; Ambrose, C.G.; Mikos, A.G. Thermally cross-linked oligo(poly(ethylene glycol) fumarate) hydrogels support osteogenic differentiation of encapsulated marrow stromal cells in vitro. Biomacromolecules 2004, 5, 5-10. [CrossRef] [PubMed]

131. Sarvestani, A.S.; He, X.; Jabbari, E. Viscoelastic characterization and modeling of gelation kinetics of injectable in situ cross-linkable poly(lactide-co-ethylene oxide-co-fumarate) hydrogels. Biomacromolecules 2007, 8, 406-415. [CrossRef] [PubMed]

132. Sarvestani, A.S.; Xu, W.; He, X.; Jabbari, E. Gelation and degradation characteristics of in situ photo-crosslinked poly(L-lactide-co-ethylene oxide-co-fumarate) hydrogels. Polymer 2007, 48, 7113-7120. [CrossRef]

133. He, X.; Ma, J.; Jabbari, E. Migration of marrow stromal cells in response to sustained release of stromal-derived factor- $1 \alpha$ from poly(lactide ethylene oxide fumarate) hydrogels. Int. J. Pharm. 2010, 390, 107-116. [CrossRef] [PubMed]

134. He, X.; Ma, J.; Mercado, A.; Xu, W.; Jabbari, E. Cytotoxicity of paclitaxel in biodegradable self-assembled core-shell poly(lactide-co-glycolide ethylene oxide fumarate) nanoparticles. Pharm. Res. 2008, 25, 1552-1562. [CrossRef] [PubMed]

135. Lee, S.Y.; Zhong, X.; Valtchev, P.; Dehghani, F. Synthesis of a biodegradable polymer in gas expanded solution: Effect of the process on cytocompatibility. Green Chem. 2013, 15, 1280-1291. [CrossRef]

136. Lee, S.; Zhong, X.; Ravarian, R.; Valtchev, P.; Dehghani, F. An approach to improve the efficiency of polymerization and enhance biological activity of poly(lactide-co-ethylene oxide fumarate) hydrogels. Polym. Sci. Polym. Chem. 2014, 52, 1291-1299. [CrossRef]

137. Fathi, A.; Lee, S.; Zhong, X.; Hon, N.; Valtchev, P.; Dehghani, F. Fabrication of interpenetrating polymer network to enhance the biological activity of synthetic hydrogels. Polymer 2013, 54, 5534-5542. [CrossRef]

138. Fathi, A.; Lee, S.; Breen, A.; Shirazi, A.N.; Valtchev, P.; Dehghani, F. Enhancing the mechanical properties and physical stability of biomimetic polymer hydrogels for micro-patterning and tissue engineering applications. Eur. Polym. J. 2014, 59, 161-170. [CrossRef]

139. Fathi, A.; Mithieux, S.M.; Wei, H.; Chrzanowski, W.; Valtchev, P.; Weiss, A.S.; Dehghani, F. Elastin based cell-laden injectable hydrogels with tunable gelation, mechanical and biodegradation properties. Biomaterials 2014, 35, 5425-5435. [CrossRef] [PubMed]

140. Fathi, A.; Dehghani, F. Antiseptic Polymer and Synthesis Thereof. AUP2015902943, 24 July 2015.

141. Fathi, A.; Dehghani, F.; Weiss, A.; Mithieux, S. Application of Thermoresponsive Bioactive Injectable Hydrogel for Bone Regeneration. AUP2015903552, 1 September 2015.

142. Dehghani, F.; Weiss, A.; Wei, H.; Mithieux, S.; Fathi, A. A Peptide-Hydrogel Composite. WO2013091001 A1, 27 June 2013.

143. Hazer, B.; Steinbüchel, A. Increased diversification of polyhydroxyalkanoates by modification reactions for industrial and medical applications. Appl. Microbiol. Biotechnol. 2007, 74, 1-12. [CrossRef] [PubMed]

144. Chen, G.-Q.; Hajnal, I.; Wu, H.; Lv, L.; Ye, J. Engineering biosynthesis mechanisms for diversifying polyhydroxyalkanoates. Trends Biotechnol. 2015, 33, 565-574. [CrossRef] [PubMed]

145. Xiao, X.-Q.; Zhao, Y.; Chen, G.-Q. The effect of 3-hydroxybutyrate and its derivatives on the growth of glial cells. Biomaterials 2007, 28, 3608-3616. [CrossRef] [PubMed]

146. Tajima, K.; Igari, T.; Nishimura, D.; Nakamura, M.; Satoh, Y.; Munekata, M. Isolation and characterization ofbacillus sp. Int005 accumulating polyhydroxyalkanoate (PHA) from gas field soil. J. Biosci. Bioeng. 2003, 95, 77-81. [CrossRef]

147. Shishatskaya, E.I.; Khlusov, I.A.; Volova, T.G. A hybrid PHB-hydroxyapatite composite for biomedical application: production, in vitro and in vivo investigation. J. Biomater. Sci. Polym. Ed. 2006, 17, 481-498. [CrossRef] [PubMed]

148. Meischel, M.; Eichler, J.; Martinelli, E.; Karr, U.; Weigel, J.; Schmöller, G.; Tschegg, E.K.; Fischerauer, S.; Weinberg, A.M.; Stanzl-Tschegg, S.E. Adhesive strength of bone-implant interfaces and in vivo degradation of PHB composites for load-bearing applications. J. Mech. Behav. Biomed. Mater. 2016, 53, 104-118. [CrossRef] [PubMed]

149. Misra, S.K.; Ansari, T.I.; Valappil, S.P.; Mohn, D.; Philip, S.E.; Stark, W.J.; Roy, I.; Knowles, J.C.; Salih, V.; Boccaccini, A.R. Poly(3-hydroxybutyrate) multifunctional composite scaffolds for tissue engineering applications. Biomaterials 2010, 31, 2806-2815. [CrossRef] [PubMed] 
150. Paşcu, E.I.; Stokes, J.; McGuinness, G.B. Electrospun composites of PHBV, silk fibroin and nano-hydroxyapatite for bone tissue engineering. Mater. Sci. Eng. C 2013, 33, 4905-4916. [CrossRef] [PubMed]

151. Wu, J.; Sun, J.; Liu, J. Evaluation of PHBV/calcium silicate composite scaffolds for cartilage tissue engineering. Appl. Surf. Sci. 2014, 317, 278-283. [CrossRef]

152. Zhang, S.; Prabhakaran, M.P.; Qin, X.; Ramakrishna, S. Biocomposite scaffolds for bone regeneration: Role of chitosan and hydroxyapatite within poly-3-hydroxybutyrate-co-3-hydroxyvalerate on mechanical properties and in vitro evaluation. J. Mech. Behav. Biomed. Mater. 2015, 51, 88-98. [CrossRef] [PubMed]

153. Avella, M.; Martuscelli, E.; Raimo, M. The fractionated crystallization phenomenon in poly(3-hydroxybutyrate) poly(ethylene oxide) blends. Polymer 1993, 34, 3234-3240. [CrossRef]

154. Francis, L.; Meng, D.; Knowles, J.C.; Roy, I.; Boccaccini, A.R. Multi-functional P(3HB) microsphere/45s5 bioglass ${ }^{\circledR}$-based composite scaffolds for bone tissue engineering. Acta Biomater. 2010, 6, 2773-2786. [CrossRef] [PubMed]

155. Amrita, A.A.; Sharma, P.; Katti, D.S. Pullulan-based composite scaffolds for bone tissue engineering: Improved osteoconductivity by pore wall mineralization. Carbohydr. Polym. 2015, 123, 180-189. [CrossRef] [PubMed]

156. Sadat-Shojai, M.; Khorasani, M.T.; Jamshidi, A.; Irani, S. Nano-hydroxyapatite reinforced polyhydroxybutyrate composites: A comprehensive study on the structural and in vitro biological properties. Mat. Sci. Eng. C Mater. 2013, 33, 2776-2787. [CrossRef] [PubMed]

157. Berger, M.; Probst, F.; Schwartz, C.; Cornelsen, M.; Seitz, H.; Ehrenfeld, M.; Otto, S. A concept for scaffold-based tissue engineering in alveolar cleft osteoplasty. J. Cranio-Maxillofac. Surg. 2015, 43, 830-836. [CrossRef] [PubMed]

158. Hao, J.Y.; Deng, X.M. Semi-interpenetrating networks of bacterial poly(3-hydroxybutyrate) with net-poly(ethylene glycol). Polymer 2001, 42, 4091-4097. [CrossRef]

159. Vroman, I.; Tighzert, L. Biodegradable polymers. Materials 2009, 2, 307. [CrossRef]

160. Bugnicourt, E.; Cinelli, P.; Lazzeri, A.; Alvarez, V. Polyhydroxyalkanoate (PHA): Review of synthesis, characteristics, processing and potential applications in packaging. Express Polym. Lett. 2014, 8, 791-808. [CrossRef]

161. Inoue, S.; Koinuma, H.; Tsuruta, T. Copolymerization of carbon dioxide and epoxide. J. Polym. Sci. Polym. Lett. 1969, 7, 287-292. [CrossRef]

162. Luinstra, G.A. Poly(propylene carbonate), old copolymers of propylene oxide and carbon dioxide with new interests: Catalysis and material properties. Polym. Rev. 2008, 48, 192-219. [CrossRef]

163. Li, X.H.; Meng, Y.Z.; Zhu, Q.; Xu, Y.; Tjong, S.C. Melt processable and biodegradable aliphatic polycarbonate derived from carbon dioxide and propylene oxide. J. Appl. Polym. Sci. 2003, 89, 3301-3308. [CrossRef]

164. Kim, G.; Ree, M.; Kim, H.; Kim, I.; Kim, J.; Lee, J. Biological affinity and biodegradability of poly(propylene carbonate) prepared from copolymerization of carbon dioxide with propylene oxide. Macromol. Res. 2008, 16, 473-480. [CrossRef]

165. Kawaguchi, T.; Nakano, M.; Juni, K.; Inoue, S.; Yoshida, Y. Examination of biodegradability of poly(ethylene carbonate) and poly(propylene carbonate) in the peritoneal cavity in rats. Chem. Pharm. Bull. 1983, 31, 1400-1403. [CrossRef] [PubMed]

166. Zhong, X.; Dehghani, F. Fabrication of biomimetic poly(propylene carbonate) scaffolds by using carbon dioxide as a solvent, monomer and foaming agent. Green Chem. 2012, 14, 2523-2533. [CrossRef]

167. Welle, A.; Kröger, M.; Döring, M.; Niederer, K.; Pindel, E.; Chronakis, I.S. Electrospun aliphatic polycarbonates as tailored tissue scaffold materials. Biomaterials 2007, 28, 2211-2219. [CrossRef] [PubMed]

168. Jing, X.; Mi, H.-Y.; Peng, J.; Peng, X.-F.; Turng, L.-S. Electrospun aligned poly(propylene carbonate) microfibers with chitosan nanofibers as tissue engineering scaffolds. Carbohydr. Polym. 2015, 117, 941-949. [CrossRef] [PubMed]

169. Zhong, X.; Lu, Z.; Valtchev, P.; Wei, H.; Zreiqat, H.; Dehghani, F. Surface modification of poly(propylene carbonate) by aminolysis and layer-by-layer assembly for enhanced cytocompatibility. Coll. Surf. B Biointerfaces 2012, 93, 75-84. [CrossRef] [PubMed]

170. Yang, G.H.; Su, J.J.; Gao, J.; Hu, X.; Geng, C.Z.; Fu, Q. Fabrication of well-controlled porous foams of graphene oxide modified poly(propylene-carbonate) using supercritical carbon dioxide and its potential tissue engineering applications. J Supercrit. Fluid 2013, 73, 1-9. [CrossRef] 
171. Lee, Y.; Kim, D.; Seo, J.; Han, H.; Khan, S.B. Preparation and characterization of poly(propylene carbonate)/exfoliated graphite nanocomposite films with improved thermal stability, mechanical properties and barrier properties. Polym. Int. 2013, 62, 1386-1394. [CrossRef]

172. Gao, G.; Feng, C.; Wang, K.; Deng, H.; Zhang, Q.; Bai, H.; Fu, Q. A promising alternative to conventional polyethylene with poly(propylene carbonate) reinforced by graphene oxide nanosheets. J. Mater. Chem. 2011, 21, 17627-17630. [CrossRef]

173. Ren, G.J.; Sheng, X.F.; Qin, Y.S.; Chen, X.S.; Wang, X.H.; Wang, F.S. Toughening of poly(propylene carbonate) using rubbery non-isocyanate polyurethane: Transition from brittle to marginally tough. Polymer 2014, 55, 5460-5468. [CrossRef]

174. Qin, Y.S.; Chen, L.J.; Wang, X.H.; Zhao, X.J.; Wang, F.S. Enhanced mechanical performance of poly(propylene carbonate) via hydrogen bonding interaction with o-lauroyl chitosan. Carbohydr. Polym. 2011, 84, 329-334. [CrossRef]

175. Wang, X.L.; Li, R.Y.; Cao, Y.X.; Meng, Y.Z. Essential work of fracture analysis for starch filled poly(propylene carbonate) composites. Mater. Des. 2007, 28, 1934-1939. [CrossRef]

176. Zeng, S.S.; Wang, S.J.; Xiao, M.; Han, D.M.; Meng, Y.Z. Preparation and properties of biodegradable blend containing poly (propylene carbonate) and starch acetate with different degrees of substitution. Carbohydr. Polym. 2011, 86, 1260-1265. [CrossRef]

177. Ma, X.F.; Chang, P.R.; Yu, J.G.; Wang, N. Preparation and properties of biodegradable poly(propylene carbonate)/thermoplastic dried starch composites. Carbohydr. Polym. 2008, 71, 229-234. [CrossRef]

178. Flynn, A.; Torres, L.F.; Orts, W.J.; Klamczynski, A. Bioderived Compatibilizer for Biopolymers. U.S. Patents US20090253871 A1, 8 October 2015.

179. Chen, C.; John Scheirs, J. Polymer/Thermoplastic Starch Compositions. EP2473542 B1, 29 July 2015.

180. Tian, L.; Wang, P.; Zhao, Z.; Ji, J. Antimicrobial activity of electrospun poly(butylenes succinate) fiber mats containing PVP-capped silver nanoparticles. Appl. Biochem. Biotechnol. 2013, 171, 1890-1899. [CrossRef] [PubMed]

181. Jeong, E.H.; Im, S.S.; Youk, J.H. Electrospinning and structural characterization of ultrafine poly(butylene succinate) fibers. Polymer 2005, 46, 9538-9543. [CrossRef]

182. Costa-Pinto, A.R.; Correlo, V.M.; Sol, P.C.; Bhattacharya, M.; Srouji, S.; Livne, E.; Reis, R.L.; Neves, N.M. Chitosan-poly(butylene succinate) scaffolds and human bone marrow stromal cells induce bone repair in a mouse calvaria model. J. Tissue Eng. Regen. Med. 2012, 6, 21-28. [CrossRef] [PubMed]

183. Zeng, J.-B.; Huang, C.-L.; Jiao, L.; Lu, X.; Wang, Y.-Z.; Wang, X.-L. Synthesis and properties of biodegradable poly(butylene succinate-co-diethylene glycol succinate) copolymers. Ind. Eng. Chem. Res. 2012, 51, 12258-12265. [CrossRef]

184. Costa-Pinto, A.R.; Correlo, V.M.; Sol, P.C.; Bhattacharya, M.; Charbord, P.; Delorme, B.; Reis, R.L.; Neves, N.M. Osteogenic differentiation of human bone marrow mesenchymal stem cells seeded on melt based chitosan scaffolds for bone tissue engineering applications. Biomacromolecules 2009, 10, 2067-2073. [CrossRef] [PubMed]

185. Oliveira, J.T.; Correlo, V.M.; Sol, P.C.; Costa-Pinto, A.R.; Malafaya, P.B.; Salgado, A.J.; Bhattacharya, M.; Charbord, P.; Neves, N.M.; Reis, R.L. Assessment of the suitability of chitosan/polybutylene succinate scaffolds seeded with mouse mesenchymal progenitor cells for a cartilage tissue engineering approach. Tissue Eng. 2008, 14, 1651-1661. [CrossRef] [PubMed]

186. Llorens, E.; Ibañez, H.; del Valle, L.J.; Puiggalí, J. Biocompatibility and drug release behavior of scaffolds prepared by coaxial electrospinning of poly(butylene succinate) and polyethylene glycol. Mater. Sci. Eng. C 2015, 49, 472-484. [CrossRef] [PubMed]

187. Deepthi, S.; Viha, C.; Thitirat, C.; Furuike, T.; Tamura, H.; Jayakumar, R. Fabrication of chitin/poly(butylene succinate)/chondroitin sulfate nanoparticles ternary composite hydrogel scaffold for skin tissue engineering. Polymers 2014, 6, 2974. [CrossRef]

188. Lim, J.S.; Kim, J.H. New application of poly(butylene succinate) (PBS) based ionomer as biopolymer: A role of ion group for hydroxyapatite (HAP) crystal formation. J. Mater. Sci. 2009, 44, 6398-6403. [CrossRef]

189. Ngamviriyavong, P.; Patntirapong, S.; Janvikul, W.; Arphavasin, S.; Meesap, P.; Singhatanadgit, W. Development of poly(butylene succinate)/calcium phosphate composites for bone engineering. Compos. Interfaces 2014, 21, 431-441. [CrossRef] 
190. Dash, T.K.; Konkimalla, V.B. Poly- $\varepsilon$-caprolactone based formulations for drug delivery and tissue engineering: A review. J. Control. Release 2012, 158, 15-33. [CrossRef] [PubMed]

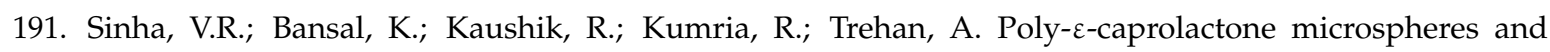
nanospheres: An overview. Int. J. Pharm. 2004, 278, 1-23. [CrossRef] [PubMed]

192. Yoshimoto, H.; Shin, Y.M.; Terai, H.; Vacanti, J.P. A biodegradable nanofiber scaffold by electrospinning and its potential for bone tissue engineering. Biomaterials 2003, 24, 2077-2082. [CrossRef]

193. Cooper, A.; Bhattarai, N.; Zhang, M. Fabrication and cellular compatibility of aligned chitosan-PCL fibers for nerve tissue regeneration. Carbohydr. Polym. 2011, 85, 149-156. [CrossRef]

194. Kim, M.; Kim, G.H. Electrohydrodynamic direct printing of PCL/collagen fibrous scaffolds with a core/shell structure for tissue engineering applications. Chem. Eng. J. 2015, 279, 317-326. [CrossRef]

195. Gautam, S.; Chou, C.-F.; Dinda, A.K.; Potdar, P.D.; Mishra, N.C. Surface modification of nanofibrous polycaprolactone/gelatin composite scaffold by collagen type I grafting for skin tissue engineering. Mater. Sci. Eng. C 2014, 34, 402-409. [CrossRef] [PubMed]

196. Kim, M.S.; Kim, G. Three-dimensional electrospun polycaprolactone (PCL)/alginate hybrid composite scaffolds. Carbohydr. Polym. 2014, 114, 213-221. [CrossRef] [PubMed]

197. Guarino, V.; Causa, F.; Taddei, P.; di Foggia, M.; Ciapetti, G.; Martini, D.; Fagnano, C.; Baldini, N.; Ambrosio, L. Polylactic acid fibre-reinforced polycaprolactone scaffolds for bone tissue engineering. Biomaterials 2008, 29, 3662-3670. [CrossRef] [PubMed]

198. Pan, L.; Pei, X.; He, R.; Wan, Q.; Wang, J. Multiwall carbon nanotubes/polycaprolactone composites for bone tissue engineering application. Coll. Surf. B Biointerfaces 2012, 93, 226-234. [CrossRef] [PubMed]

199. Kim, M.; Kim, G. Electrospun PCL/phlorotannin nanofibres for tissue engineering: Physical properties and cellular activities. Carbohydr. Polym. 2012, 90, 592-601. [CrossRef] [PubMed]

200. Lee, H.; Hwang, H.; Kim, Y.; Jeon, H.; Kim, G. Physical and bioactive properties of multi-layered PCL/silica composite scaffolds for bone tissue regeneration. Chem. Eng. J. 2014, 250, 399-408. [CrossRef]

201. Dziadek, M.; Menaszek, E.; Zagrajczuk, B.; Pawlik, J.; Cholewa-Kowalska, K. New generation poly ( $\varepsilon$-caprolactone)/gel-derived bioactive glass composites for bone tissue engineering: Part I. Material properties. Mater. Sci. Eng. C 2015, 56, 9-21. [CrossRef] [PubMed]

202. Mohammadkhah, A.; Marquardt, L.M.; Sakiyama-Elbert, S.E.; Day, D.E.; Harkins, A.B. Fabrication and characterization of poly- $(\varepsilon)$-caprolactone and bioactive glass composites for tissue engineering applications. Mater. Sci. Eng. C 2015, 49, 632-639. [CrossRef] [PubMed]

203. Lei, B.; Shin, K.-H.; Noh, D.-Y.; Jo, I.-H.; Koh, Y.-H.; Kim, H.-E.; Kim, S.E. Sol-gel derived nanoscale bioactive glass (nBG) particles reinforced poly( $\varepsilon$-caprolactone) composites for bone tissue engineering. Mater. Sci. Eng. C 2013, 33, 1102-1108. [CrossRef] [PubMed]

204. Zhao, X.; Lui, Y.S.; Choo, C.K.C.; Sow, W.T.; Huang, C.L.; Ng, K.W.; Tan, L.P.; Loo, J.S.C. Calcium phosphate coated keratin-PCL scaffolds for potential bone tissue regeneration. Mater. Sci. Eng. C 2015, 49, 746-753. [CrossRef] [PubMed]

205. Pok, S.; Myers, J.D.; Madihally, S.V.; Jacot, J.G. A multilayered scaffold of a chitosan and gelatin hydrogel supported by a PCL core for cardiac tissue engineering. Acta Biomater. 2013, 9, 5630-5642. [CrossRef] [PubMed]

206. Biscaia, S.I.; Viana, T.F.; Almeida, H.A.; Bártolo, P.J. Production and characterisation of PCL/es scaffolds for bone tissue engineering. Mater. Today Proc. 2015, 2, 208-216. [CrossRef]

207. Gautam, S.; Dinda, A.K.; Mishra, N.C. Fabrication and characterization of PCL/gelatin composite nanofibrous scaffold for tissue engineering applications by electrospinning method. Mater. Sci. Eng. C 2013, 33, 1228-1235. [CrossRef] [PubMed]

208. Annabi, N.; Fathi, A.; Mithieux, S.M.; Weiss, A.S.; Dehghani, F. Fabrication of porous PCL/elastin composite scaffolds for tissue engineering applications. J. Supercrit. Fluids 2011, 59, 157-167. [CrossRef]

209. Annabi, N.; Fathi, A.; Mithieux, S.M.; Martens, P.; Weiss, A.S.; Dehghani, F. The effect of elastin on chondrocyte adhesion and proliferation on poly ( $\varepsilon$-caprolactone)/elastin composites. Biomaterials 2011, 32, 1517-1525. [CrossRef] [PubMed]

210. Patrício, T.; Domingos, M.; Gloria, A.; Bártolo, P. Characterisation of PCL and PCL/PLA scaffolds for tissue engineering. Procedia CIRP 2013, 5, 110-114. [CrossRef] 
211. Williamson, M.R.; Black, R.; Kielty, C. PCL-PU composite vascular scaffold production for vascular tissue engineering: Attachment, proliferation and bioactivity of human vascular endothelial cells. Biomaterials 2006, 27, 3608-3616. [CrossRef] [PubMed]

212. Hoque, M.E.; Meng, T.T.H.; Chuan, Y.L.; Chowdhury, M.; Prasad, R.G.S.V. Fabrication and characterization of hybrid PCL/PEG 3D scaffolds for potential tissue engineering applications. Mater. Lett. 2014, 131, 255-258. [CrossRef]

213. Mabrouk, M.; Bijukumar, D.; Mulla, J.A.S.; Chejara, D.R.; Badhe, R.V.; Choonara, Y.E.; Kumar, P.; du Toit, L.C.; Pillay, V. Enhancement of the biomineralization and cellular adhesivity of polycaprolactone-based hollow porous microspheres via dopamine bio-activation for tissue engineering applications. Mater. Lett. 2015, 161, 503-507. [CrossRef]

214. Shor, L.; Güçeri, S.; Wen, X.; Gandhi, M.; Sun, W. Fabrication of three-dimensional polycaprolactone/hydroxyapatite tissue scaffolds and osteoblast-scaffold interactions in vitro. Biomaterials 2007, 28, 5291-5297. [CrossRef] [PubMed]

215. Fabbri, P.; Cannillo, V.; Sola, A.; Dorigato, A.; Chiellini, F. Highly porous polycaprolactone-45s5 bioglass ${ }^{\circledR}$ scaffolds for bone tissue engineering. Compos. Sci. Technol. 2010, 70, 1869-1878. [CrossRef]

216. Shim, W.S.; Yoo, J.S.; Bae, Y.H.; Lee, D.S. Novel injectable $\mathrm{pH}$ and temperature sensitive block copolymer hydrogel. Biomacromolecules 2005, 6, 2930-2934. [CrossRef] [PubMed]

217. Fu, S.; Ni, P.; Wang, B.; Chu, B.; Zheng, L.; Luo, F.; Luo, J.; Qian, Z. Injectable and thermo-sensitive PEG-PCL-PEG copolymer/collagen/n-HA hydrogel composite for guided bone regeneration. Biomaterials 2012, 33, 4801-4809. [CrossRef] [PubMed]

218. Hwang, M.J.; Joo, M.K.; Choi, B.G.; Park, M.H.; Hamley, I.W.; Jeong, B. Multiple sol-gel transitions of PEG-PCL-PEG triblock copolymer aqueous solution. Macromol. Rapid Commun. 2010, 31, 2064-2069. [CrossRef] [PubMed]

219. Hwang, M.J.; Suh, J.M.; Bae, Y.H.; Kim, S.W.; Jeong, B. Caprolactonic poloxamer analog: PEG-PCL-PEG. Biomacromolecules 2005, 6, 885-890. [CrossRef] [PubMed]

220. Miao, B.; Song, C.; Ma, G. Injectable thermosensitive hydrogels for intra-articular delivery of methotrexate. J. Appl. Polym. Sci. 2011, 122, 2139-2145. [CrossRef]

221. Li, Z.; Tan, B.H. Towards the development of polycaprolactone based amphiphilic block copolymers: Molecular design, self-assembly and biomedical applications. Mater. Sci. Eng. C 2014, 45, 620-634. [CrossRef] [PubMed]

222. Cai, L.; Wang, S. Poly( $\varepsilon$-caprolactone) acrylates synthesized using a facile method for fabricating networks to achieve controllable physicochemical properties and tunable cell responses. Polymer 2010, 51, 164-177. [CrossRef]

223. Ranjha, N.; Mudassir, J.; Majeed, S. Synthesis and characterization of polycaprolactone/acrylic acid (PCL/AA) hydrogel for controlled drug delivery. Bull. Mater. Sci. 2011, 34, 1537-1547. [CrossRef]

224. Rieger, J.; Van Butsele, K.; Lecomte, P.; Detrembleur, C.; Jerome, R.; Jerome, C. Versatile functionalization and grafting of poly( $\varepsilon$-caprolactone) by michael-type addition. Chem. Commun. 2005, 2, 274-276. [CrossRef] [PubMed]

225. Wang, S.; Lu, L.; Gruetzmacher, J.A.; Currier, B.L.; Yaszemski, M.J. A biodegradable and cross-linkable multiblock copolymer consisting of poly(propylene fumarate) and poly( $\varepsilon$-caprolactone): Synthesis, characterization, and physical properties. Macromolecules 2005, 38, 7358-7370. [CrossRef]

226. Boffito, M.; Sirianni, P.; Di Rienzo, A.M.; Chiono, V. Thermosensitive block copolymer hydrogels based on poly( $\varepsilon$-caprolactone) and polyethylene glycol for biomedical applications: State of the art and future perspectives. J. Biomed. Mater. Res. 2015, 103, 1276-1290. [CrossRef] [PubMed]

227. Peng, R.; Qin, G.; Li, X.; Lv, H.; Qian, Z.; Yu, L. The PEG-PCL-PEG hydrogel as an implanted ophthalmic delivery system after glaucoma filtration surgery; a pilot study. Med. Hypothesis Discov. Innov. Ophthalmol. 2014, 3, 3-8. [PubMed]

228. Lin, T.-C.; Hung, K.-H.; Peng, C.-H.; Liu, J.-H.; Woung, L.-C.; Tsai, C.-Y.; Chen, S.-J.; Chen, Y.-T.; Hsu, C.-C. Nanotechnology-based drug delivery treatments and specific targeting therapy for age-related macular degeneration. J. Chin. Med. Assoc. 2015, 78, 635-641. [CrossRef] [PubMed]

229. Hu, W.-W.; Elkasabi, Y.; Chen, H.-Y.; Zhang, Y.; Lahann, J.; Hollister, S.J.; Krebsbach, P.H. The use of reactive polymer coatings to facilitate gene delivery from poly ( $\varepsilon$-caprolactone) scaffolds. Biomaterials 2009, 30, 5785-5792. [CrossRef] [PubMed] 
230. Riva, R.; Lenoir, S.; Jérôme, R.; Lecomte, P. Functionalization of poly( $\varepsilon$-caprolactone) by pendant hydroxyl, carboxylic acid and epoxide groups by atom transfer radical addition. Polymer 2005, 46, 8511-8518. [CrossRef]

231. Hu, X.; Chen, X.; Xie, Z.; Cheng, H.; Jing, X. Aliphatic poly(ester-carbonate)s bearing amino groups and its rgd peptide grafting. J. Polym. Sci. Polym. Chem. 2008, 46, 7022-7032. [CrossRef]

232. Kasper, F.K.; Tanahashi, K.; Fisher, J.P.; Mikos, A.G. Synthesis of poly(propylene fumarate). Nat. Protoc. 2009, 4, 518-525. [CrossRef] [PubMed]

233. Wang, M.O.; Piard, C.M.; Melchiorri, A.; Dreher, M.L.; Fisher, J.P. Evaluating changes in structure and cytotoxicity during in vitro degradation of three-dimensional printed scaffolds. Tissue Eng. 2015, 21, 1642-1653. [CrossRef] [PubMed]

234. Wang, M.O.; Etheridge, J.M.; Thompson, J.A.; Vorwald, C.E.; Dean, D.; Fisher, J.P. Evaluation of the in vitro cytotoxicity of cross-linked biomaterials. Biomacromolecules 2013, 14, 1321-1329. [CrossRef] [PubMed]

235. Wang, S.; Lu, L.; Yaszemski, M.J. Bone-tissue-engineering material poly(propylene fumarate): Correlation between molecular weight, chain dimensions, and physical properties. Biomacromolecules 2006, 7, 1976-1982. [CrossRef] [PubMed]

236. Fisher, J.P.; Vehof, J.W.M.; Dean, D.; van, d.W.J.P.C.M.; Holland, T.A.; Mikos, A.G.; Jansen, J.A. Soft and hard tissue response to photocrosslinked poly(propylene fumarate) scaffolds in a rabbit model. J. Biomed. Mater. Res. 2002, 59, 547-556. [CrossRef] [PubMed]

237. Bracaglia, L.G.; Yu, L.; Hibino, N.; Fisher, J.P. Reinforced pericardium as a hybrid material for cardiovascular applications. Tissue Eng. 2014, 20, 2807-2816. [CrossRef] [PubMed]

238. He, S.; J. Yaszemski, M.; Yasko, A.W.; Engel, P.S.; Mikos, A.G. Injectable biodegradable polymer composites based on poly(propylene fumarate) crosslinked with poly(ethylene glycol)-dimethacrylate. Biomaterials 2000, 21, 2389-2394. [CrossRef]

239. He, S.; Timmer, M.D.; Yaszemski, M.J.; Yasko, A.W.; Engel, P.S.; Mikos, A.G. Synthesis of biodegradable poly(propylene fumarate) networks with poly(propylene fumarate)-diacrylate macromers as crosslinking agents and characterization of their degradation products. Polymer 2001, 42, 1251-1260. [CrossRef]

240. Timmer, M.D.; Ambrose, C.G.; Mikos, A.G. In vitro degradation of polymeric networks of poly(propylene fumarate) and the crosslinking macromer poly(propylene fumarate)-diacrylate. Biomaterials 2003, 24, 571-577. [CrossRef]

241. Horch, R.A.; Shahid, N.; Mistry, A.S.; Timmer, M.D.; Mikos, A.G.; Barron, A.R. Nanoreinforcement of poly(propylene fumarate)-based networks with surface modified alumoxane nanoparticles for bone tissue engineering. Biomacromolecules 2004, 5, 1990-1998. [CrossRef] [PubMed]

242. Fisher, J.P.; Dean, D.; Mikos, A.G. Photocrosslinking characteristics and mechanical properties of diethyl fumarate/poly(propylene fumarate) biomaterials. Biomaterials 2002, 23, 4333-4343. [CrossRef]

243. Wang, K.; Cai, L.; Wang, S. Methacryl-polyhedral oligomeric silsesquioxane as a crosslinker for expediting photo-crosslinking of poly(propylene fumarate): Material properties and bone cell behavior. Polymer 2011, 52, 2827-2839. [CrossRef]

244. Kim, K.; Dean, D.; Wallace, J.; Breithaupt, R.; Mikos, A.G.; Fisher, J.P. The influence of stereolithographic scaffold architecture and composition on osteogenic signal expression with rat bone marrow stromal cells. Biomaterials 2011, 32, 3750-3763. [CrossRef] [PubMed]

245. Yan, J.; Li, J.; Runge, M.B.; Dadsetan, M.; Chen, Q.; Lu, L.; Yaszemski, M.J. Cross-linking characteristics and mechanical properties of an injectable biomaterial composed of polypropylene fumarate and polycaprolactone co-polymer. J. Biomater. Sci. Polym. Ed. 2011, 22, 489-504. [CrossRef] [PubMed]

246. Brandi, F.; Anjum, F.; Ceseracciu, L.; Barone, A.C.; Athanassiou, A. Rigid biodegradable photopolymer structures of high resolution using deep-UV laser photocuring. J. Micromech. Microeng. 2011. [CrossRef]

247. Cai, L.; Wang, K.; Wang, S. Poly(ethylene glycol)-grafted poly(propylene fumarate) networks and parabolic dependence of MC3T3 cell behavior on the network composition. Biomaterials 2010, 31, 4457-4466. [CrossRef] [PubMed]

248. Danti, S.; D'Alessandro, D.; Pietrabissa, A.; Petrini, M.; Berrettini, S. Development of tissue-engineered substitutes of the ear ossicles: Porp-shaped poly(propylene fumarate)-based scaffolds cultured with human mesenchymal stromal cells. J. Biomed. Mater. Res. 2010, 92, 1343-1356. [CrossRef] [PubMed]

249. Cai, L.; Wang, S. Parabolic dependence of material properties and cell behavior on the composition of polymer networks via simultaneously controlling crosslinking density and crystallinity. Biomaterials 2010, 31, 7423-7434. [CrossRef] [PubMed] 
250. Thankam, F.G.; Muthu, J. Biosynthetic hydrogels-Studies on chemical and physical characteristics on long-term cellular response for tissue engineering. J. Biomed. Mater. Res. 2014, 102, 2238-2247. [CrossRef] [PubMed]

251. Thankam, F.G.; Muthu, J. Infiltration and sustenance of viability of cells by amphiphilic biosynthetic biodegradable hydrogels. J. Mater. Sci. Mater. Med. 2014, 25, 1953-1965. [CrossRef] [PubMed]

252. Shung, A.K.; Behravesh, E.; Jo, S.; Mikos, A.G. Crosslinking characteristics of and cell adhesion to an injectable poly(propylene fumarate-co-ethylene glycol) hydrogel using a water-soluble crosslinking system. Tissue Eng. 2003, 9, 243-254. [CrossRef] [PubMed]

253. Tanahashi, K.; Mikos, A.G. Protein adsorption and smooth muscle cell adhesion on biodegradable agmatine-modified poly(propylene fumarate-co-ethylene glycol) hydrogels. J. Biomed. Mater. Res. 2003, 67, 448-457. [CrossRef] [PubMed]

254. Tanahashi, K.; Mikos, A.G. Cell adhesion on poly(propylene fumarate-co-ethylene glycol) hydrogels. J. Biomed. Mater. Res. 2002, 62, 558-566. [CrossRef] [PubMed]

255. Tanahashi, K.; Jo, S.; Mikos, A.G. Synthesis and characterization of biodegradable cationic poly(propylene fumarate-co-ethylene glycol) copolymer hydrogels modified with agmatine for enhanced cell adhesion. Biomacromolecules 2002, 3, 1030-1037. [CrossRef] [PubMed]

256. Tanahashi, K.; Mikos, A.G. Effect of hydrophilicity and agmatine modification on degradation of poly(propylene fumarate-co-ethylene glycol) hydrogels. J. Biomed. Mater. Res. 2003, 67, 1148-1154.

257. Cai, L.; Chen, J.; Rondinone, A.J.; Wang, S. Injectable and biodegradable nanohybrid polymers with simultaneously enhanced stiffness and toughness for bone repair. Adv. Funct. Mater. 2012, 22, 3181-3190. [CrossRef]

(C) 2016 by the authors; licensee MDPI, Basel, Switzerland. This article is an open access article distributed under the terms and conditions of the Creative Commons by Attribution (CC-BY) license (http://creativecommons.org/licenses/by/4.0/). 